\title{
CONFUCIUS CROSSES THE SOUTH SEAS
}

\section{Henri Chambert-Loir}

\section{CONFUCIUS OUTWITTED}

Once upon a time, the "prophet" Confucius (wali Khong Hoe Tjoe) went out of his residence, in the country of Lokok, to "go and teach the Moslems of the back-country." On his way, he met a few boys busy playing, except one who was standing by himself and was building a toy fort in the middle of the road. Confucius asked him why he was not playing with his friends. The boy, named Hang Thok, replied with a detailed exposition of the bad consequences of playing. Surprised, the prophet ordered him to move his fort, so that he could go by with his cart, but the boy refused with a witty excuse. Even more surprised, the prophet offered to take the boy on a tour, then to play cards, but both offers were again rejected. Then Confucius asked various questions and riddles, which were all easily answered by the boy. Among others, Confucius asked:

According to you, who is closer: one's father and mother or one's wife?

Hang Thok answered:

$\mathrm{O}$, my lord, I believe father and mother are closer.

Because Confucius believed that there was no relationship closer than that of husband and wife ("one in life and one in death"), he thought that he had trapped the boy at last. But Hang Thok explained that that relationship is transitory and can be replaced if necessary:

Henri Chambert-Loir is a research fellow at the University of Malaya, Kuala Lumpur. 
$\mathrm{O}$, my lord, don't get upset. When a man's wife dies, it is like a carriage that has lost a wheel, one makes a new one, right? It can even be stronger, better, and more enjoyable. This is how it goes with husband and wife.

The boy further explained that one's relation to one's father and mother is everlasting and irreplaceable:

- Many stars scintillate in the sky, but their light can't compare with that of the one moon. The same goes with a father's and a mother's love: it is infinite.

Then Hang Thok directed questions to the prophet. First, why do geese and ducks swim, why do mynahs have a piercing voice, and why do banyan trees have evergreen leaves? Confucius gave answers, but the boy easily showed they were wrong. Then he asked how many stars there are in the sky and how many houses on earth. Confucius rejected both questions, arguing that it was enough to talk about "what is in front of our eyes." Then Hang Thok gave the fatal blow with the question : "In that case, how many eyebrows do you have?"

Fully defeated, Confucius walked away while wondering where that boy came from; perhaps he was a god incarnate.

\section{The Malay Versions}

This tale, the text and translation of which are to be found at the end of this article, was published in two installments in the Malay newspaper Bintang Soerabaia in 1888 (nos. 161 and 163, July 16 and 19), and signed by one T. T. La. The same story, with a number of variants, appeared in various schoolbooks for Chinese children in Batavia between the years 1870 and $1930 .{ }^{1}$ Copies of those books are extremely rare nowadays. I have been able to consult only two of them, dated 1884 and 1929. In the latter one (Boekoe pladjaran 1929) the story is said to be "quoted from the Siauw Dji Loen," or Xiao er lun, "conversation with a small boy." ${ }^{2}$ Indeed, it is translated from the Chinese.

\footnotetext{
${ }^{1}$ Nine such books are known, as follows: (1) Boekoe peladjaran boewat anak-anak bergoena aken mengenal letter Olanda (Batavia: Kolff \& Co., 1878), 40 pp. [third ed., 1880, 40 pp.]; (2) Boekoe peladjaran bergoena pada anakanak aken mengenalken letter Olanda (Batavia: Yap Goan Ho, Tjitakan jang pertama, 1884), 88 pp. [third ed., 1889; fourth ed., 1892, 91 pp.l; (3) Boekoe peladjaran bergoena pada anak-anak mengenalken letter Olanda, first ed (Batavia: n.p., 1885), 60 pp.; (4) San tzŭ ching. Boekoe pladjaran beralamat "Iboe bapa tjinta anak": Djin Tjie Hjee dan A.B.C. (Batavia: Gooan Hoong \& Co., 1894), two vol., 256 pp.; (5) Boekoe peladjaran bergoena pada anakanak akan mengenalken letter Olanda, fifth ed. (Batavia: Kho Tjeng Bie \& Co., 1904 [tenth ed., 1922]); (6) Boekoe pladjaran A.B.C. jang bergoena boeat anak-anak boeat mengenal Letter Olanda Bahasa Melajoe (Weltevreden: Tjio Kim Siong, 1922 [third ed., Batavia: Kho Tjeng Bie, 1930]); (7) Boekoe peladjaran A.B.C.Khong Hoe Tjoe: Ditjeritakan Nabi Khong Hoe Tjoe main bade-badean pada satoe anak ketjil bernama Hang Thok. Terkoetip dari boekoe Siauw Dji Loen (Batavia: Goan Hong \& Co., 1929), 32 pp.; (8) Boekoe peladjaran bergoena boeat anak-anak akan mengenalken letter Olanda dan Melajoe (Arab), third ed. (Batavia: Kho Tjeng Bie \& Co., 1930), 71 pp. [eleventh ed., 1932/1933, 96 pp.]); and (9) Boekoe pladjaran A.B.C. bergoena boeat anak-anak akan mengenal letter Olanda bahasa Melajoe (Batavia: Sunrise, [1939]), 92 pp. I express my deepest gratitude to Claudine Salmon, who provided me with all three Malay versions of the text as well as other materials and all kinds of information and insights related to this topic. Many thanks are also due to Charles A. Coppel, for providing me with various materials and references, and for his challenging comments on an earlier draft of this paper. A number of Chinese words and names are quoted in this article, mainly according to their modern Indonesian form, and I tried to provide their pinyin transcription. As I have no knowledge of Chinese, all these transcriptions are borrowed from the various publications quoted below.

${ }^{2}$ Claudine Salmon and Denys Lombard, "Confucianisme et esprit de réforme dans les communautés chinoises d'Insulinde (fin XIXe-début XXe siècle)," in En suivant la voie royale: Mélanges offerts en hommage à Léon Vandermeersch, ed. Jacques Gernet and Marc Kalinowski (Paris: EFEO, 1997): 382.
} 

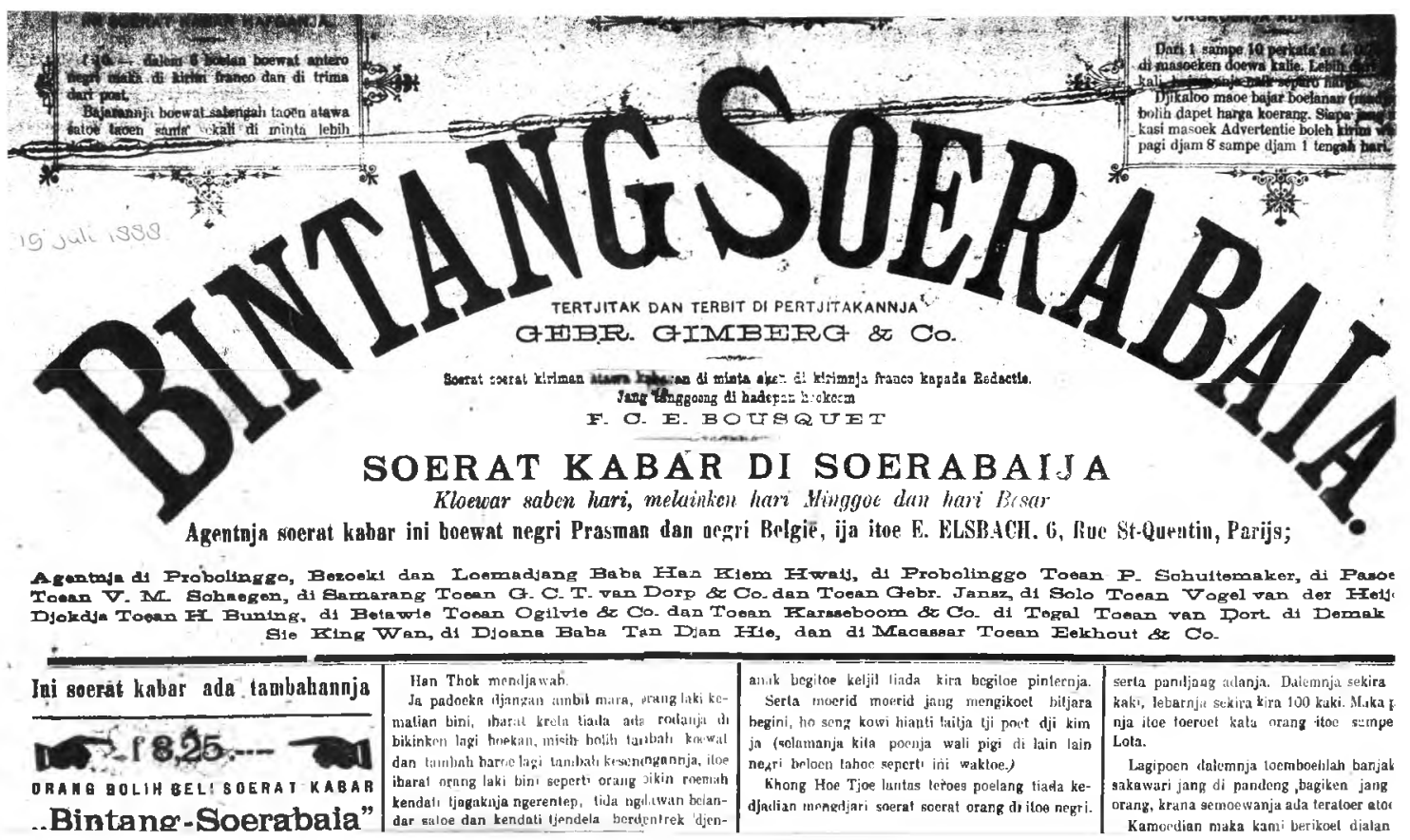

Figure 1. Bintang Soerabaia, July 19, 1888, containing the second part of the tale of Hang Thok.

Those three versions (that of Bintang Soerabaia and the two schoolbooks) are written in a variety of Malay typical of the Malay texts published by Chinese writers about Chinese culture at the end of the nineteenth century, that is, Low Malay in Latin script mixed with a number of Hokkien words. It is also heavily influenced by Javanese. There is actually a fourth version of the Malay text, which is quite different in that it is written in Jawi script by a Moslem. That version is found in a manuscript kept in St Petersburg and dating from the early years of the twentieth century. ${ }^{3}$ The manuscript contains a collection of 153 tales authored or at least copied by Ahmad Beramka. Most of the tales come from a Malay version of the One Thousand and One Nights (probably through an earlier translation, maybe that of G. Francis in 1891-1902 or that of Lie Kim Hok and F. Wiggers in 1886) ${ }^{4}$, but some tales and some poems (syair) in the manuscript

${ }^{3}$ Cod. C 1966 in the collection of the Academy of Sciences; see: V. I. Braginsky and M. A. Boldyreva, Naskhah-naskhah Melayu Koleksi Lembaga Pengajian Timur, Akademi Ilmu Pengetahuan Unie Soviet Cawangan Leningrad (Bangi: Universiti Kebangsaan Malaysia, Institut Bahasa, Kesusasteraan dan Kebudayaan Melayu, 1988); and V. I. Braginsky and M. A. Boldyreva, "Les manuscrits malais de Leningrad," Archipel 40 (1990): $153-78$.

${ }^{4}$ About these three authors, see: Pramoedya Ananta Toer, Tempo Doeloe: Antologi Satra Pra-Indonesia (Jakarta: Lentera Dipantara, 2003), 30-32, 43-48 [first edition, 1982]; and Claudine Salmon, Literature in Malay by the Chinese of Indonesia: A Provisional Bibliography (Paris: Maison des Sciences de l'Homme, 1981), 228-30. Of Lie Kim Hok and F. Wiggers's translation, we only know stories forty-one to ninety-four, but there were probably other installments that are lost today. Gijsbert Francis's translation-Gijsbert Francis, Hikajat 1001 Malam, ja-itoe Tjeritera-tjeritera Arab, disalin kepada Bahasa Melajoe oleh Toean Gijsbert Francis, Redacteur dari soerat kabar 'Pembrita Betawi' dengan menoeroet karangan Toean Gerard Keller di dalam bahasa Olanda. Terhias dengan lebih daripada 300 gambar jang bagoes-bagoes (Betawi: Albrecht \& Rusche, 1891-1902), incomplete in thirty-two installments and $1583 \mathrm{pp}$.- is quite extraordinary among books of the time. The title makes clear that Gijsbert Francis (it seems that his first name is only known through this very reference) has translated the Dutch version by Gerard Keller and that the book contains more than three hundred etchings, "jang bagoes-bagoes." Those etchings, most probably reproduced from the Dutch version, 
come from other sources. The story of Hang Thok is tale no. 151, entitled "The Master and the Small Boys" (Guru dan anak-anak kecil). I know the beginning of the tale only: an old and revered master is surrounded by his numerous disciples; a boy is building a demolish it, as he wants to go by; ...
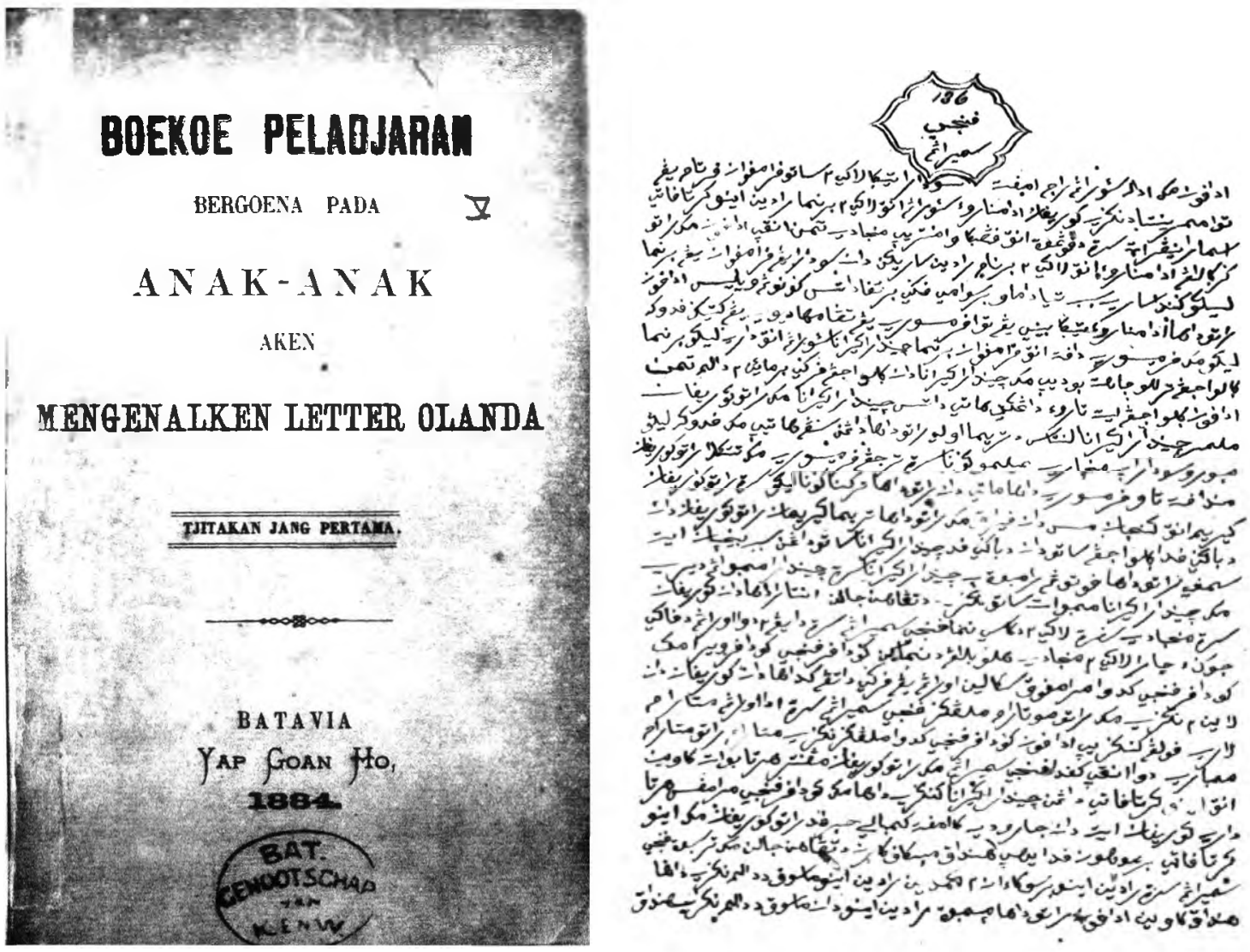

Figure 2 (left). The 1884 schoolbook, title page. Figure 3 (right). A page of the manuscript C 1966 in St. Petersburg, opening with tale 136, "Panji Semirang."

Source: Braginsky \& Boldyreva, "Les manuscrits malais de Leningrad."

What is most interesting about this version is that it is integrated into a Jawi text intended for a Malay audience. Ahmad Beramka is known for having transmitted to his Malay audience a number of stories written by Chinese authors. 5 This is precisely what he did with the Confucian tale, making it part of Malay folklore of some sort. Figures 2 and 3 illustrate the juxtaposition of two contrasting worlds: on the one hand, a printed book in Latin characters produced by a Chinese publisher, an icon of

are typical of the period and indeed remarkable. The book was published in forty installments (see Nio Joe Lan, Sastera Indonesia-Tionghoa [Djakarta: Gunung Agung, 1962], 21), but it was apparently not popular because written in "Melayu tinggi."

${ }^{5}$ See Henri Chambert-Loir, "Sair Java-Bank di rampok: littérature malaise ou sino-malaise?" in Le moment "sino-malais" de la littérature indonésienne, ed. Claudine Salmon (Paris: Archipel, 1992), 43-70. 
modernity in that year, 1884. On the other hand, some twenty years later, a manuscript in Jawi script produced by a Moslem author, the very symbol of Malay tradition.

\section{Many More Versions}

Sixty years ago, the sinologist Michel Soymié devoted a long study to the Confucius-Hang Thok tale, in which he reveals that the text exists in the following languages: Chinese, Tibetan, Mongol, Thai, and Japanese. To which we can now add Manchu, Khmer, Vietnamese, Malay, and Javanese. ${ }^{6}$

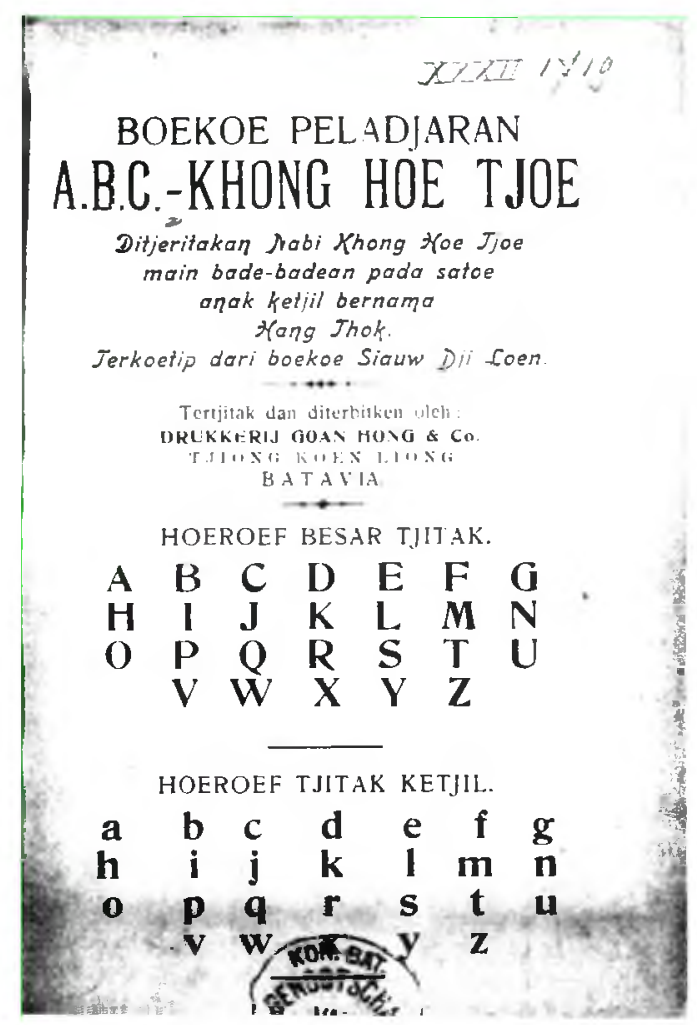

Figure 4. The 1929 schoolbook, title page.

Soymié himself edits and translates one ancient and one modern Chinese version of the tale and gives summaries of the Tibetan, Mongol, Japanese, and Thai versions. The modern Chinese version comes from a schoolbook printed in 1864 and was also published in various Cantonese almanacs up to the early twentieth century, while the ancient Chinese version (twelve manuscripts) and the Tibetan one (two manuscripts)

\footnotetext{
"See Michel Soymié, "L'entrevue de Confucius et de Hiang T'o," Journal Asiatique 242 (1954): 311-92. An edition and summary of the Khmer text is found in Khing Hoc Dy, "Note sur l'histoire de Khun Cuv et Cau Thuk, version khmère de l'entrevue entre Confucius et un jeune garçon" (in Cambodian), in Khing Hoc Dy, Rasmei Kamm Aksor sel chen loe kampuchea nea satavoat ti 19 noeng ti 20: Le rayonnement littéraire chinois sur le Cambodge des XIXe et XXe siècles (Phnom Penh: Angkor, 2008); and an edition and translation of the Javanese one in Dede Oetomo, "Serat Ang Dok: A Confucian treatise in Javanese," Archipel 34 (1987): 181-97.
} 
come from the famous Dunhuang caves, in present day Gansu province, in the far northwest of China. Those caves, containing an enormous collection of manuscripts, were sealed in the early eleventh century, to be discovered some nine hundred years later, in the early twentieth century. The Dunhuang manuscripts of the story of Xiang Tuo (the Malay Hang Thok) date from the fifth to eleventh centuries. But Soymié also remarks that the tale is quoted in older Chinese texts, namely in eight texts dating from the period of the second century BCE to the third century CE. ${ }^{7}$ This means that the anecdote about Hang Thok, if not the tale itself, is much more ancient than the texts we know. Moreover, according to recent information, ${ }^{8}$ the first known mention of Xiang Tuo is found in a text regarding the Warring States (403-221 BCE). The text (Zhan guo ce, "Intrigues of the Warring States") says that "Confucius took Xiang Tuo as a master" and a sentence of exactly the same meaning is used in a handbook for children, "The Three Character Classic," that has been used in China for centuries (it dates back to either the Song or the Ming dynasty) and was published in Malay in $1895 .{ }^{9}$ Presently, the anecdote about Xiang Tuo is much discussed on the Internet, where other Chinese versions unknown to Soymié are mentioned.

In other words, the tale has been transmitted within China itself continuously for at least twenty-four centuries and, very early on, it was translated into Tibetan and other "northern" languages. But, as far as we know, it was only in the nineteenth century that it was also translated into Southeast Asian languages.

It may seem strange that a tale in which Confucius is ridiculed by a country boy should be inserted in schoolbooks. The basic idea of the text may be the philosophical axiom that the greatest philosopher only has a limited knowledge of the world, but why is it that the first image of Confucius given to children should be a derogatory one? In some versions of the text, Confucius is ashamed or disgruntled or even furious, but in general he is only bewildered and admiring, while his inferiority is sometimes explained by the supposition that the boy is actually a god incarnate.

It is not altogether clear whether Xiang Tuo was a historical figure. From the earliest quotations collected by Soymié, it transpires that he had already become a legendary character symbolizing child prodigies. He is represented in Han reliefs together with Confucius and Lao-tzu; he is quoted on the twelfth-century tombstone of a child; he is supposed to have died when ten years old; he is the little boy-god invoked by mediums. In this light, it is only fitting that Hang Thok should be presented to children as a model: he epitomizes the knowledge and wisdom that a child should aspire to possess.

Southeast Asian Chinese should have been aware of this. When using the tale as a reading exercise, they were following an ageless tradition (the Dunhuang manuscripts, prior to the eleventh century, were already copies made by schoolchildren) that had transmitted across the centuries the fame of the child prodigy. However, the tale is liable to be misunderstood. As learned a scholar as Nio Joe Lan, talking of an " $\mathrm{ABC}$ "

\footnotetext{
${ }^{7}$ Soymié, “L'entrevue de Confucius et de Hiang T'o," 367-71.

${ }^{8}$ Claudine Salmon, personal communications, February-June 2014.

${ }^{9}$ See Kitab Peladjaran Sam Djie King pada menjatakan permoelä̈n beladjar membatja dengan 1053 hoeroef Tjina beralamat "Tboe Bapa tjinta anak" hoeroef Tjina dan hoeroef Olanda bahasa Hokkien dan bahasa Khee ja-itoe A.B.C. dan Djin Tjie Tjee, first ed. (Batavia-Solo: Albrecht \& Rusche, 1895), 2 vol., 255 pp., trans. Tjiong Hok Long.
} 
schoolbook he knew from an advertisement, containing the "story of Confucius playing riddles with the young boy Hang Thok," wrote this in 1962:

The author of the book was not aware that the story of Khong Hoe Tjoe debating with the young boy Hang Thok was precisely the work of a Chinese author opposed to the teachings of Khong Tjoe. In that story Khong Tjoe is defeated by the boy! Therefore, as a reading material intended to inspire a better appreciation of Khong Tjoe to children, it is not a good choice. And as furthermore that story is based on Chinese philosophy, it is not appropriate as reading matter for children! $!^{10}$

I should think that such a misreading of the tale is typical of the period following the 1920s, that is, after Confucianism had been attacked in the Sino-Malay press as a consequence of the rise of Chinese nationalism. ${ }^{11}$

\section{Variation}

It would be useful to make a detailed comparison of all versions, to try and draw their stemma (their genealogical tree) and to underscore the peculiarities of each one. Those distinguishing details are the result of the transformation of the tale during its diffusion and the process of its translation, following four types of transformation: expansion, reduction, inversion, and modification. Such an endeavour would require many more sources than we have now, and, considering the origin of the tale and the number of texts, it should be undertaken by a sinologist. I will restrict myself here to a few remarks on those various transformations inasmuch as they throw light on the Malay version.

I say "the Malay version," but there are actually a few. I know of four, as already mentioned: the version published in Bintang Soerabaia, summarized above; two published in schoolbooks in 1884 and 1929 (the second known from an incomplete copy only); and that of Ahmad Beramka (which I have not had an opportunity to read in full). Differences among the first three crop up in every episode, although it is obvious that the first two are quite close to each other while the third one is notably different. It seems that, in the same way, the text has been known in more or less diverging versions in all countries involved, and this is also true of the Chinese versions. Therefore, the single ancient Chinese text we have (that published by Soymié) is only one among others and in no way the starting point of the foreign versions, even though it is clear that the story has its origin in China. As an example, Soymié mentions that the episode of the viviparous bird that is found only in the Tibetan version is probably inspired from a Chinese version we don't know. He also remarks that the Chinese so-called "modern" version (known from an 1864 publication) ultimately stems from a source as old as the so-called "ancient" one, that is, prior to the early eleventh century. ${ }^{12}$ In other words, the "modern" version is in some way just as

\footnotetext{
${ }^{10}$ Nio Joe Lan, Sastera Indonesia-Tionghoa, 134-35.

${ }^{11}$ On these polemics, see Charles A. Coppel, "Is Confucianism a religion? A 1923 Debate in Java," Archipel 38 (1989): 125-35. A new debate was raised in the 1950s and 1960s, contemporary to Nio's publication; see Charles A. Coppel, "Khong Kauw: Confucian Religion in Indonesia," in Studying Ethnic Chinese in Indonesia, ed. Coppel (Singapore: Singapore Society of Asian Studies, 2002), 235-36.

${ }^{12}$ Soymié, "L'entrevue de Confucius et de Hiang T'o," 363 (viviparous bird), 364 (ancient versus modern).
} 
old as the "ancient" one. There are in the ancient version three episodes that are inverted compared to the modern one; in the three cases, the modern version appears more logical and so probably better reflects the original tale than does the ancient one.

There are no two identical versions. Some have an additional episode that is not found in others. Some omit an episode found in most others. The nature of the differences suggests that oral transmission has played an important part in the diffusion of the tale. It is probable, for instance, that the four Malay versions are not the transcription or translation of one or more texts, but rather independent redactions produced from memory by four different individuals. ${ }^{13}$ The structure of the narration is perfectly identical, but a large number of details are different. One example will suffice to illustrate this. One of the questions asked by Confucius was difficult to render in Malay because it implies knowledge of the Chinese calendar. The two Chinese versions have the following (quoting Soymie):

Ancient version: "What days are not enough, what days are superabundant?"

Modern version: "What is not enough, what is superabundant?"

This in Malay becomes:

Bintang Soerabaia: "What in this world can be less and what can be more?" (di doenja apa jang bisa koerang dan apa jang bisa lebih)

Boekoe P. (1884): "How come some people say incomplete and some say overabundant?" (pegimana ada ijang bilang tiada sampe dan ada ijang bilang lebi?)

Boekoe P. (1929): "What is said to be not enough? What is said to be in excess?" (Bagimana jang terbilang tiada tjoekoep? Bagimana jang terbilang ada lebih?)

We see that the notion of days in the ancient Chinese version is absent here, as it is in the modern Chinese one. However, the answers do concern the calendar:

Ancient and modern Chinese versions alike: "Winter days are not enough, summer days are in excess"

Bintang Soerabaia: "The tenth Chinese month has more days, there is an excess; the sixth Chinese month has fewer days, there is a shortage." (Tjina boelan 10 hari ada pandjang temtoe ada lebih. Tjina boelan 6 hari ada pendek temtoe ada koerang.)

Boekoe P. (1884): "the Tjap Gwe month has fewer days, the Lak Gwe month has more." (Boelan Tjap Gwe arinja pendek! Boelan Lak Gwe arinja pandjang!)

Boekoe P. (1929): "The Tang season (the tenth, eleventh, and twelfth months) has fewer days, that's what is said not enough; the He season (the fourth, fifth, and sixth months) has more days, that's what is said in excess." (Moesim 'Tang' [boelan ka 10, 11 dan 12 harinja pinda], terbilang tiada tjoekoep! Moesim 'He' [boelan ka 4, 5 dan 6 lagi pandjang] terbilang ada lebih!)

\footnotetext{
${ }^{13}$ In two places in the 1888 Malay version, however, a variant might be the consequence of the misreading of a written text. First, that version has "a mouse deer" against "a rabbit" in other versions, which could be due to the misreading of kancil for kelinci. Second, that version has the poor example of "a horse" against "a frog" in other versions, which could be due to the misreading of kuda for kodok. These two examples might be signs that the story has once circulated in written form in the Arabic script.
} 
The three answers are notably different, with a growing degree of technicity (Tjap Gwe is the tenth Chinese month, Lak Gwe the sixth; Tang is winter and He summer). Those texts have clearly been written by people who have some knowledge of the Chinese calendar. (It is a fact that in the Chinese calendar, the months at the end of the year-fall and winter-are shorter than those at the beginning-spring and summer.) The Javanese version has solved the difficulty by adjusting the answer to the local milieu: "What is 'not enough' like? How can it be 'more than enough'?" The answer then becomes, "In between rice harvests, there is not enough rice to eat; harvest time brings more than enough." ${ }^{14}$

A very few variants suggest an opposition between the versions of the Chinese and Sinicized worlds, or of the North (ancient and modern Chinese, Tibetan, Mongol, and Japanese versions) and those of the South, that is Southeast Asia (Khmer, Siamese, Malay, and Javanese versions). As an example, at the beginning of the tale, in the Northern versions, Confucius goes out of his residence to go on an excursion, whereas in most Southern versions he goes teaching-with the exception of the 1929 Malay and the Javanese versions, which share the Northern variant. It never happens that such an opposition involves all versions. It is only in the ancient Chinese, Tibetan, and Mongol versions that Hang Thok is insolent and Confucius violent. The Southeast Asian versions seem to stem from the model of the modern Chinese version, with which they share some variants in opposition to the Northern versions. In any case, the three Malay versions I could read are certainly closer to the modern than to the ancient Chinese version. The apparent impossibility of building a stemma on the basis of the variants of the narrative suggests that (with the exception of the Mongol version, which is adapted from the Tibetan one ${ }^{15}$ ) the various versions in each language stem independently from a Chinese source, but there are different Chinese sources. It is clear that the Javanese version was not translated from the Malay.

\section{Localization}

Besides the wide range of variation due to transmission, most versions have been in some ways localized, that is, adapted to the local milieu, both ecological and religious. In many versions local animals and plants have been substituted for the typically Chinese ones. In the Indonesian versions, for instance, pines and cypress have been replaced by banyans (beringin, waringin). In the Malay version, below, the hare becomes a mouse deer; the adult name ( $t s e u$, unknown in Java) becomes the name of a school; and Chinese chess is replaced by a more familiar Chinese game (cuki). One of the most interesting of these adaptations is the substitution of "key to the revolution of Yin and Yang" in the modern Chinese version with "the head and tail of the world and the hereafter" in two Malay versions, with use of the typically Islamic word akhirat (kapala dan boentoetnja doenia dengen Acherat). This kind of indigenization of the tale tends to make it more intelligible. It also shows that the rendering of the tale into various foreign languages is not meant to be a translation of a text but rather the transmission of a story. In that regard, it is interesting that the Javanese version should be more inventive than the Malay one.

\footnotetext{
${ }^{14}$ Oetomo, "Serat Ang Dok," 187-88.

${ }^{15}$ Soymié, "L'entrevue de Confucius et de Hiang T'o," 366.
} 
The religious adjustments are of the same nature. In one of the numerous tales about the previous lives of the Buddha, the Sambhava Jataka, a king looking for a definition of benevolence and truth, sends a Brahmin to consult all the wise men of India, but he finally obtains the answer from a seven-year old boy named Sambhava. ${ }^{16}$ On that basis, one Mongol version dating back to the thirteenth century or later has transformed the Confucian tale into the confrontation between a poor boy perched on an ox and a Brahmin infatuated with his knowledge, to the disadvantage, of course, of the Brahmin. ${ }^{17}$

Independent of such early tales, the much later Khmer version, of which there are no less than seven manuscripts, has also been given a Buddhist tint. The story, "taken from the illustrious Pali Law," happens in a peaceful and prosperous Buddhist kingdom, probably located in India. At the end, Khun Cuv (Confucius) remarks that Cau Thuk (Xiang Tuo) will "become a bud of the Enlightened in this world [i.e., a Bodhisattva]" and that the kingdom will benefit from such an erudite man. ${ }^{18}$

Similarly, the Malay text has been provided with a few hints at Islam. First, the qualification of Confucius as wali and nabi (saint and prophet); second, the mention that natural phenomena are due to the will of Allah ta'ala ("toean allah ta'allah soeda nitahken," "itoe ada toewan Allah Ta Allah soeda tentoeken begitoe," and "Itoe Allah ta'alah jang soeda takdirken"); and, third, the fact that Confucius left his residence to teach the people of the "Islamic country" (negeri bangsa Islam) in the back country of Lokok. In Ahmad Beramka's version, as we have seen, Hang Thok builds a toy house in the shape of a mosque.

The Javanese version goes a bit further. The story is said to be taken from a "holy book from China" (koran saking Cina) and Confucius teaches Islamic students (santri) to read the Quran (mengaji) in a typically Islamic institution (langgar). The mention of Moslems in Confucius's time is somewhat preposterous, but in this case, just as in the Malay versions, there is no attempt to Islamize the tale; it is only interspersed with a very few Islamic elements that tend to actualize it, to make it more familiar and more meaningful, and to show that the authority of the Master extends to the Moslem populations. In a similar way, a biography of Confucius published in 1924 in the form of a Malay syair uses Malay words of Arabic origin with a strong Islamic connotation, like midrasa for Confucius's school, perang sabilloela about the war between two Chinese kingdoms, kitab for Chinese books, and Allah as Confucius's protector. ${ }^{19}$

\section{Schoolbooks}

Most of the Malay versions of the story were published in handbooks for Chinese schools. The sole complete story that I was able to consult (the one published in 1884) amounts to eighty-eight pages and reveals to be impressively well composed, considering what we know of Chinese education of the time. It starts with eleven Latin alphabets in different fonts, followed by twenty-six reading exercises (beladjar sepel),

\footnotetext{
${ }^{16}$ Ibid., 388.

${ }^{17}$ Ibid., 357.

${ }^{18}$ Khing, "Note sur l'histoire de Khun Cuv et Cau Thuk," 62.

${ }^{19}$ See H. Brightson-Kediri, Sair Pengidoepan Nabie Khong Hoe Tjoe (Kediri: Boedi-Karjo, 1924).
} 
the first sixteen of them for deciphering syllables and words, then short texts containing elementary civics (e.g., "If someone is evil or wicked, people should gather and admonish him in such a way that he will be scared ${ }^{20}$ ). Following that are the figures from one to ten million in both Malay and Dutch, multiplication tables, month names in Dutch, Chinese, Malay, and Javanese (e.g., Januari, Tji-goe-e, Moeharam, Soera), and one lesson on punctuation. Then comes a fourteen-page story in which pupils, in front of their teacher, show off their zeal for learning and their contempt for playing, which artificially leads to a list of the Malay and Dutch names of animals and body parts. Then the teacher declares: "Now, look at the story of a prophet named Kong Tjoe Kong or Kong Hoe Tjoe with gods disguised as young boys playing in the middle of the road," and so starts our Confucian tale. ${ }^{21}$ That is followed by a list of administrative units (regencies, afdeelingen, and districts) of the Netherlands Indies ("Tambahan, boeat mengenalken negri-negri jang termasoek bilangannja Maha Radja Olanda"), and, finally, by a few advices for writing official letters. ${ }^{22}$ Someone mastering all this material, in 1884 , would have been quite learned.

This is all the more surprising because, before 1901 and the opening of modern schools by the Tiong Hoa Hwe Koan (see below), education for the Chinese was singularly poor. Chinese children were not (or only rarely) admitted either to the schools for Dutch children or the government schools for native children that opened after $1854 .{ }^{23}$ Instead there were four kinds of Chinese schools, all equally inefficient. The first kind was the Gie Oh (yixue, "gratuitous schools"), dating back to the eighteenth century, and depending on the Kong Koan, the administration of the Chinese captains. Pupils were taught to read extracts of Chinese classics according to their own language: Hokkien, Hakka, Kongfu, etc., without understanding their meaning. ${ }^{24}$ Writing in 1879 , a Dutch observer noted that school premises were in a terrible condition. ${ }^{25}$ In 1878 , the total number of pupils in Java schools was 3,452 ; in 1899 , it had increased to 4,452 , that is, less than 2 percent of the Chinese population. ${ }^{26}$

The second kind of school involved some rich families inviting tutors from China to come and educate their children, and giving other children in the neighborhood the opportunity to follow such teaching. The method of teaching was the same as in the

\footnotetext{
${ }^{20}$ Boekoe peladjaran bergoena pada anak-anak aken mengenalken letter Olanda, 20.

${ }^{21}$ Ibid., 52-66.

${ }^{22}$ Ibid., 67-86 for administrative units; $87-88$ for letter-writing.

${ }^{23}$ See, for eample, Donald E. Willmott, The Chinese of Semarang: A Changing Minority Community in Indonesia (Ithaca: Cornell University Press, 1960), 19.

${ }^{24}$ See: Nio Joe Lan, Riwajat 40 Taon Tiong Hoa Hwe Koan-Batavia (Batavia: Tiong Hoa Hwe Koan, 1940), 21-22; Kwee Tek Hoay, "A tsal moelahnja timboel pergerakan Tionghoa jang modern di Indonesia," Moestika Romans, no. 73-84 (1926-39): 34-56, reproduced with modern spelling in Kesastran Melayu Tionghoa dan Kebangsaan Indonesia, ed. Marcus A. S. and Pax Benedanto, vol. 4 (Jakarta: Kepustakaan Populer Gramedia, 2001), 393-534; and Tek Hoay Kwee, The Origins of the Modern Chinese Movement in Indonesia, ed. and trans. Lea E. Williams (Ithaca: Cornell Southeast Asia Program Publications, 1969), 22.

${ }^{25}$ M. J. E. Albrecht, "Het Schoolonderwijs onder de Chineezen op Java," Tijdschrift van het Bataviaasch Genootschap 25 (1879): 230.

${ }^{26}$ See: James R. Rush, "Placing the Chinese in Java on the Eve of the Twentieth Century," Indonesia, special issue (proceedings), The role of the Indonesian Chinese in Shaping Modern Indonesian life (1991), 22; and Charles A. Coppel, "The Origins of Confucianism as an Organized Religion in Java, 1900-1923," Journal of Southeast Asian Studies 12, no. 1 (1981): 181, reproduced in Coppel, Studying Ethnic Chinese in Indonesia (Singapore: Singapore Society of Asian Studies, 2002).
} 
Gie Oh. ${ }^{27}$ Some of those tutors eventually opened private schools, and there were eleven of them in Batavia at the end of the 1870s, each taking care of fifteen to twenty pupils. ${ }^{28}$ Only boys were sent to school, for a maximum of about twelve years (from seven to nineteen years of age), but usually for less than that. In the Gie Oh and tutoring schools, the teaching was so bad that most of the boys, afterward, were unable to read or write a simple letter. ${ }^{29}$ We will see the exceptional case of a Chinese scholar who opened a modern school under the patronage of Confucius in Surabaya in the early 1880 s.

The third kind of school amounted to private schools opened by Peranakan Chinese, where the teaching was given in Malay. ${ }^{30}$ And, finally, the fourth kind were schools opened by Dutch missionaries for local children, but where the majority of the pupils were, in fact Chinese. ${ }^{31}$

The school primers containing the Confucian tale fit badly in this picture. Being in Malay, not in Chinese, these books apparently could only have been printed to be used in the Peranakan or the missionary schools, but the student population attending those types of schools was too small to have had so many editions printed. Moreover, the missionary schools were primarily intended for Sundanese children and would not have used Chinese materials in their curricula, not to mention the Javanese tint of the Malay used in the books, too.

\section{Confucianism as a Religion}

The tale in itself is simple. Its origin not long after the death of Confucius and its persistent transmission in Chinese culture are interesting topics in relation to the history of Confucianism in China. Its translation into nine Asian languages and its modifications to accommodate a variety of ecological and religious environments is another instructive story. Those translations were made and spread in different contexts. The Malay version, as we have seen, is noticeably different from the Javanese one, let alone versions belonging to cultural contexts that are even further afield, such as the Khmer translation.

As interesting as the literary and philological aspects of the tale may be, its significance lies in its social and religious context. To understand why the Malay tale

${ }^{27}$ Salmon and Lombard, "Confucianisme et esprit de réforme," 386.

${ }^{28}$ Albrecht, "Het Schoolonderwijs," 228, 233.

${ }^{29}$ Ibid., 240.

${ }^{30}$ Claudine Salmon, "Le sjair de l" Association chinoise' de Batavia (1905)," Archipel 2 (1971): 55-100. For an Indonesian translation, see Claudine Salmon, "Syair Tiong Hwa Hwe Kwan Batavia (1905)," in Sastra Indonesia Awal: Kontribusi Orang Tionghoa, ed. C. Salmon (Jakarta: Kepustakaan Populer Gramedia-EFEO), 279-316, esp. 296.

${ }^{31}$ See Charles A. Coppel, "From Christian Mission to Confucian Religion: The Nederlandsche Zendingsvereeniging and the Chinese of West Java, 1870-1910," in Nineteenth and Twentieth Century Indonesia: Essays in Honour of Professor J. D. Legge, ed. D. P. Chandler and M. C. Ricklefs (Clayton: Monash Universty, 1986), 15-39, reproduced in Coppel, Studying Ethnic Chinese in Indonesia, 291-312. A few authors mention that, in the late nineteenth century, retired Dutch civil servants opened private schools in Batavia, but none gives any details about these. See, for example, Nio Joe Lan, Sastera Indonesia-Tionghoa; and Leo Suryadinata, "Indonesian Chinese Education, Past and Present," Indonesia 14 (October 1972): 4-5, and reproduced in L. Suryadinata, The Chinese Minority in Indonesia: Seven Papers (Singapore: Chopmen Enterprises, 1978). 
was published in Batavia around 1880 and the meaning it could have for a specific group at that time, it is necessary to investigate various aspects of the Chinese community in Java in the nineteenth century as well as the history of Confucianism in Indonesia. What was the place of Confucius's teachings in the culture of the Chinese around 1880? Were they taught or studied? Were they available in Malay translation? Were they applied in family and social life? Did they already exhibit characteristics of belonging to a cult or a religion?

This is all the more interesting today since Confucianism has become one of the six religions officially recognized in Indonesia. The way in which Confucianism came to be recognized as a religion can be briefly summarized as follows. The 1945 Constitution of the Republic of Indonesia guarantees all citizens the freedom of worship according to their own religion, provided it adheres to a "belief in the One and Only God." Then, in 1952, the concept of religion was defined by a ministerial decree (Peraturan Menteri Agama No. 9/1952), that is, a religion (agama) had to acknowledge one God and have a sacred book (kitab suci), a prophet (nabi), and a code of values, and it could not be limited to one ethnic group. Later, in 1960, the parliament specified that only "world religions" would receive government legitimation (Ketetapan MPRS No. II/MPRS/1960). Then, in January 1965, President Soekarno issued a decree forbiding the misuse and abuse of religions (Penetapan Presiden No. 1/1965 tentang Pentjegahan Penjalahgunaan dan/atau Penodaan Agama), in the appended gloss of which (Pendjelasan) the relevant religions were defined as being only Islam, Protestantism, Catholicism, Hinduism, Buddhism, and Confucianism. This decree was enacted as law four years later, under Soeharto's presidency (Undang-Undang No. 5, 1969). ${ }^{32}$

What is even more generally ignored is that Soekarno's 1965 decree, which was given force of law in 1969 and is thus still actual, does not limit the number of recognized religions to six: on the contrary, it leaves the list open and explicitly mentions four more religions by name, including Judaism. The text says:

The religions practiced by the people of Indonesia are Islam, Protestantism, Catholicism, Hinduism, Buddhism, and Confucianism. This can be proven by the history of Indonesian religions ... This does not mean that other religions, for instance, Judaism, Zoroastrianism, Shintoism, and Taoism, are forbidden in Indonesia. They have the full guarantee provided by paragraph 29 article 2 [of the constitution] and they are permitted to exist under the condition they do not infringe the dispositions of this decree or any other legal disposition. ${ }^{33}$

\footnotetext{
${ }^{32}$ Thanks to Michel Picard for information on this. See Julia Day Howell, "Modernizing Religious Reform and the Far Eastern Religions in Twentieth Century Indonesia," in Spectrum: Essays Presented to Sutan Takdir Alisjahbana on his Seventieth Birthday, ed. S. Udin (Jakarta: Dian Rakyat, 1978), 274.

${ }_{33}$ "Agama-agama yang dipeluk oleh penduduk di Indonesia ialah Islam, Kristen, Katolik, Hindu, Budha dan khong $\mathrm{Cu}$ (Confusius). Hal ini dapat dibuktikan dalam sejarah perkembangan Agama-agama di Indonesia. [...] Ini tidak berarti bahwa agama-agama lain, misalnya: Yahudi, Zarasustrian, Shinto, Taoism dilarang di Indonesia. Mereka mendapat jaminan penuh seperti yang diberikan oleh pasal 29 ayat 2 dan mereka dibiarkan adanya, asal tidak melanggar ketentuan-ketentuan yang terdapat dalam peraturan ini atau peraturan perundangan lain." See Penetapan Presiden No. 1/1965, http:/ / www.kemenag.go.id/ file/ dokumen/UU1PNPS65.pdf, accessed December 11, 2014.
} 
This is an ironic illustration of the gap between law and practice, and it helps to explain how Confucianism could subsequently be tacitly removed from the list. ${ }^{34}$

Soeharto was at first favorable to Confucianism and his government had good relations with MATAKIN (Majelis Tinggi Agama Konghucu Indonesia, Supreme Council for Confucian Religion in Indonesia), which was participating in Golkar's campaigns. Soeharto gave an opening address at MATAKIN's national convention in August 1967, in which he explicitly mentioned "the Confucian religion" (agama Khonghucu). Later, however, the overall assimilationist policy of Soeharto's regime led to the banning of everything specifically Chinese, including Confucianism. A Directive of the Minister of Home Affairs-No. 477/74054/BA.01.2/4683/95, issued on November 18, 1978-spelled out the recognized religions as five in number, that is, it eliminated Confucianism. This was sustained by another Directive of the Minister of Home Affairs-No. 77/2535/POUD, issued on July 25, 1990-which confirmed that there were only five recognized religions.

The reversal, some twenty years later, was due to the short presidency of Abdurrahman Wahid. In his Instruction No. 477/805/Sj of March 2000, the Minister of Home Affairs repealed the above-mentioned 1978 instruction of his predecessor, implicitly revoking the elimination of Confucianism. It is on this rather fragile ground that Confucianism was re-listed, until a 2006 decision of the Minister of Religion again officially recognized Confucianism as a religion (Surat Keputusan Menteri Agama No.12, of 24 Jan. 2006). The number of its followers, however, had severely declined due to Soeharto's vigorous assimilationist policy. In 1971 they represented 0.8 percent of the population (almost a million individuals), but only 0.24 percent (fewer than 300,000 ) in 2000. It seems, however, that Confucianism has experienced a resurgence in the years since. ${ }^{35}$

MATAKIN is at the head of this small community. ${ }^{36}$ It has helped, over a few decades, to develop Confucianism into a proper religion (Agama Khonghucu) according

\footnotetext{
${ }^{34}$ The following information is mainly drawn from: Leo Suryadinata, "Confucianism in Indonesia, past and present," Southeast Asia 3, no. 3 (Spring 1974): 881-903, and reproduced in L. Suryadinata, The Chinese Minority in Indonesia; Leo Suryadinata, "Buddhism and Confucianism in Contemporary Indonesia: Recent Developments," in Chinese Indonesians: Remembering, Distorting, Forgetting, ed. Tim Lindsey and Helen Pausacker (Singapore and Clayton: ISEAS and Monash Asia Institute, 2005), 77-94; Andrew J. Abalahin, "A Sixth Religion? Confucianism and the Negociation of Indonesian-Chinese Identity under the Pancasila State," in Spirited Politics: Religion and Public Life in Contemporary Southeast Asia, ed. Andrew C. Willford and Kenneth M. George (Ithaca: Cornell Southeast Asia Program Publications, 2005), 119-42; Charles A. Coppel, "The Chinese Minority: Politics or Culture?" in People and Society in Indonesia: A Bibliographical Approach, ed. Leonard Y. Andaya, Charles Coppel, and Yuji Suzuki (Clayton: Monash University, 1977), 12-30, and reproduced in Coppel, Studying Ethnic Chinese in Indonesia, 48-64; Charles A. Coppel, "Contemporary Confucianism in Indonesia," in Proceedings of the Seventh IAHA Conference held at Bangkok, 22-26 August 1977, vol. 2 (Bangkok: IAHA, 1979), 739-57, and reproduced in Coppel, Studying Ethnic Chinese in Indonesia, 243-55; Heriyanto Yang, "The History and Legal Position of Confucianism in PostIndependence Indonesia," Marburg Journal of Religion (online) 10-1 (2005): 1-8; and Yumi Kitamura, "The Question of Identity and Religion in Post-Suharto Era: Successful Negotiations over the Re-recognition of Confucianism as a 'Religion," in Proceedings of the CSEAS-Netherlands Institute of War Documentation Joint International Workshop on "Chinese Identities and Inter-ethnic Coexistence and Cooperation in Southeast Asia," ed. Caroline Hau and Nobuhiro Aizawa (Kyoto: CSEAS, 2009), 227-41.

${ }^{35}$ See Susy Ong, "Ethnic Chinese Religions: Some Recent Developments," in Ethnic Chinese in Contemporary Indonesia, ed. Leo Suryadinata (Singapore: ISEAS, 2008), 110.

${ }^{36}$ The head organization had been created in 1923 in Bandung under the name of Khong Kauw Tjong Hwee (Federation of Confucian Religion Societies), then replaced by another federation established in
} 
to the Indonesian concept of agama, complete with a supreme God (Thian, previously understood as "heaven"), a prophet (Confucius), sacred revealed scriptures (the Four Books, Su Si, published as a book resembling the Bible), and a clergy. This is partly new, but as we have seen in the tale of Hang Thok, Confucius had been called a prophet (Nabi) for a long time already.

The rise of Confucianism as a social and then a religious movement in Indonesia started much earlier though, and it was brought about by the need felt by the Chinese community to assert its cultural identity.

\section{The Chinese Identity in Question}

In the political, social, and cultural situation at the end of the nineteenth century, the Chinese community in Java was led to question its own identity. Causes are manifold: among others, the colonial policy of the Dutch, the flow of new immigrants, the increasing influence of the press, and the situation in China. The Chinese community was polarized according to status (Peranakan versus Totok, that is, creoles as opposed to newcomers) and ethnic and linguistic origin (the majority being Hokkien, but with more and more Hakka, Teochiu, and Kongfu immigrants). The Peranakan families had settled on Java across the centuries (the Han family of Surabaya came to Java around 1700), ${ }^{37}$ adapting themselves to the local society in various ways and developing a mixed, creole culture, and usually giving up the use of the Chinese language. In the nineteenth century, authority and wealth were in the hands of the Peranakan elite, who were growing more powerful socially and economically, so that the Totok had little choice but to try and find a position at the bottom of the hierarchy. ${ }^{38}$

In the 1870s, the Chinese in Java and Madura represented less than 1 percent of the population, ${ }^{39}$ but they had a prominent role in the local economy by acting as gobetweens for the Dutch government and the local population. The situation in Java (or in the Netherlands Indies) is not unique. A comparison of the Chinese community in Java with those of other Southeast Asian countries allows us to differentiate what is peculiar to the former and what is the consequence of common historical circumstances. This comparison, sketched out by G. W. Skinner in 1996, shows that, for reasons that are clearly beyond the scope of this article, the Chinese were assimilated into the local societies of Thailand, Cambodia, and Burma, whereas they created creole communities in Java, the Philippines, and the Straits Settlements. In the three latter

\footnotetext{
Surakarta around 1940. In 1955, it had been replaced again by the Perserikatan Khung Chiao Hui Indonesia (PKCHI, Federation of the Confucian Associations of Indonesia, its Chinese name still being Khong Kauw Tjong Hwee). Later, the name was changed to Gabungan Perhimpunan Agama Khonghucu se-Indonesia (GAPAKSI, Federation of the Confucian Religious Associations of all Indonesia). Then, in 1967, the name was changed again, to Majelis Tinggi Agama Khonghucu Indonesia (MATAKIN).

${ }^{37}$ Claudine Salmon, "La communauté chinoise de Surabaya: Essai d'histoire, des origines à la crise de 1930," Archipel 53 (1997): 132.

${ }^{38}$ G. William Skinner, "Creolized Chinese Societies in Southeast Asia," in Sojourners and Settlers: Histories of Southeast Asia and the Chinese, ed. Anthony Reid (St. Leonards, NSW: Allen \& Unwin, 1996), 80-81.

${ }^{39}$ But they constituted almost a fourth of the population of Batavia; see Lea A. Williams, Overseas Chinese Nationalism: The Genesis of the Pan Chinese Movement in Indonesia (1900-1916) (Glencoe: The Free Press, 1960), 11.
} 
countries, the association of the Chinese with colonial exploitation was a major determinant of their social condition. The colonial powers gave the Chinese the opportunity to acquire wealth and social status, but they imposed a strict distinction between Chinese and natives. Toward the end of the nineteenth century, Skinner explains, "as the global economy shifted from commercial to industrial capitalism, colonial policy moved away from free trade toward managed economies under strengthened state control. Colonial rule became more intensive, more bureaucratic, and more efficient." ${ }^{\prime 4}$ In the Philippines, just as in Java, the creoles (Peranakan), not the newcomers (Totok), dominated the Chinese communities, but these communities (and that of the Straits, too) were transformed by the massive immigration of the late nineteenth century. ${ }^{41}$

In some cases the Chinese in Java were integrated into the Dutch administration. The Han family of East Java, for instance, whose story has been related with an exceptional wealth of details, ${ }^{42}$ is an outstanding example. At the beginning of the nineteenth century, the Moslem branch of the family, namely one man and his eight sons, controlled the whole Eastern Salient (Oosthoek) as bupatis (regents), patihs (viceregents), and tax collectors of the main towns, but they were suddenly discharged of their functions in 1818:

Behind the numerous and conflicting accusations brought against these civil servants, the covert intention of the colonial Government to regain control over the Oosthoek by eliminating men of exceptional ability, who through their internal cohesion and their matrimonial links with the Chinese and the Priyayi worlds, could have constituted a menace to the Dutch order, shows through." ${ }^{43}$

Another and more general role of the Chinese all over Java was managing revenue farms (i.e., collecting taxes on markets, cattle slaughtering, consumption of certain goods, betting, transportation, and more), running pawnshops, and distributing opium. The renting out of provinces to the Chinese as well as farming out the right to levy taxes had been done earlier by native rulers in Java, and was later adopted by the Dutch. ${ }^{44}$

The social status of the Chinese marked them as aliens. At the beginning of the nineteenth century, the Dutch government created, mostly for the Chinese, the Arabs and the Indians, the classification "foreign Orientals" (Vreemde Oosterlingen). ${ }^{45}$ When

\footnotetext{
${ }^{40}$ Skinner, "Creolized Chinese Societies in Southeast Asia," 85.

${ }^{41}$ Ibid., $83,85$.

${ }^{42}$ See Claudine Salmon, "The Han Family of East Java: Entrepreneurship and Politics (18th-19th Centuries)," Archipel 41 (1991): 53-87.

${ }^{43}$ Ibid., 74.

${ }^{44}$ See: Victor Purcell, The Chinese in Southeast Asia (London: Oxford University Press, 1966 [1951]), 407; and Peter Carey, "Changing Javanese Perceptions of the Chinese Communities in Central Java, 1755-1825," Indonesia 37 (April 1984): 9, 17, 19

${ }^{45}$ In several sources this governmental decision is dated to 1854, but, according to Mona Lohanda, it dates at least from 1818; see M. Lohanda, Growing Pains: The Chinese and the Dutch in Colonial Java, 1890-1942 (Jakarta: Yayasan Cipta Loka Caraka, 2002), 79. Purcell mentions "Foreign Orientals" in 1848 (although this could be a retroactive denomination)-see Purcell, The Chinese in Southeast Asia, 435. Charles A. Coppel, "The Indonesian Chinese: 'Foreign Orientals,' Netherlands Subjects, and Indonesian Citizens," in Law and the Chinese in Southeast Asia, ed. M. Barry Hooker (Singapore: CSEAS, 2002), 131-49, argues that in
} 
the parliament in The Hague, in 1899, gave to the Japanese in the Dutch Indies the same status as the Europeans, the Chinese resented this as an injustice. ${ }^{46}$ Following the words of a reader's letter published in the journal Hindia-Nederland, on January 8, 1881, "We Chinese who live in the Dutch East Indies are like orang menoempang [like staying at somebody's place] ..." ${ }^{47}$

Chinese were not authorized to wear European clothes or to cut their pigtails (taucang). They were treated with disdain by European bureaucrats and with violence by the indigenous police. ${ }^{48}$ They were not free to live where they wanted or to travel around; they were compelled to stay in assigned quarters in the cities and could not go from one place to another, even very short distances, without a pass. Those regulations (wijkenstelsel and passenstelsel) were ancient, dating to 1628 and 1740 , respectively, but they were reactualized and generalized in 1854 and strengthened in $1863 .{ }^{49}$ Employees of the opium and revenue farms, however, had free access to the countryside and could in that way build a commercial activity. When the farms were progressively abolished during the course of the second half of the nineteenth century, the Chinese lost not only the benefit of the farms but also the biggest part of their commercial network. The farm on markets (bazaarpacht) was abolished in 1851, the opium farm between 1894 and $1904 .{ }^{50}$

During the same period, as well as earlier in the Straits Settlements and the Philippines, the development of a liberal economic policy created the need for a substantial addition of manpower and thus provoked an influx of new immigrants, with the result that the number of Chinese living in Java rose by 45 percent between 1870 and $1900 .{ }^{51}$ In China, the ban on emigration was officially removed in 1894 , but it had long been a dead letter by that time. ${ }^{52}$ Meanwhile the Chinese government was paying more and more attention to the Chinese migrants in Southeast Asia, both as national subjects and as potential supporters from a political and financial point of view. ${ }^{53} \mathrm{~A}$ Chinese consulate was established in Singapore as early as $1877,{ }^{54}$ and, in

the nineteenth century the division of society was twofold - rather than three, as elaborated by Furnivallbut this is true on a legal grounds only, not socially or racially.

${ }^{46}$ See: Purcell, The Chinese in Southeast Asia, 436; Barbara Watson Andaya, "From Rum to Tokyo: The Search for Anticolonial Allies by the Rulers of Riau, 1899-1914," Indonesia 24 (October 1977): 134-35; and Charles A. Coppel, "The Indonesian Chinese: 'Foreign Orientals', Netherlands Subjects, and Indonesian Citizens," in Coppel, Studying Ethnic Chinese in Indonesia, 134.

${ }^{47}$ Ahmat Adam, The Vernacular Press and the Emergence of Modern Indonesian Consciousness (1855-1913) (Ithaca: Cornell Southeast Asia Program Publications, 1995), 60.

${ }^{48}$ Williams, Overseas Chinese Nationalism, 40-41.

${ }^{49}$ Ibid., 28; Lohanda, Growing Pains, 37.

${ }^{50}$ See: Lohanda, Growing Pains, 210; James R. Rush, Opium to Java: Revenue Farming and Chinese Enterprise in Colonial Indonesia, 1860-1910 (Ithaca: Cornell University Press, 1990); and James R. Rush, Opium to Java: Jawa dalam Cengkeraman Bandar-Bandar Opium Cina, Indonesia Kolonial 1860-1910, Indonesian trans. E. Setiyawati Alkhatab (Yogyakarta: Matabangsa, 2000), 464, 512.

${ }^{51}$ See: Rush, Opium to Java (2000), 526; and Skinner, "Creolized Chinese Societies in Southeast Asia," 85.

${ }^{52}$ Purcell, The Chinese in Southeast Asia, 436.

${ }^{53}$ See: Tjoe Bou-san, Pergerakan Tionghoa di Hindia Olanda dan Mr. P.H. Fromberg Sr. (Petikan artikel-artikel dari "Sin Po") (Batavia: Drukkerij Sin Po, 1921), 61; and Willmott, The Chinese of Semarang, 24-25.

${ }^{54}$ Yen Ching-hwang, Coolies and Mandarins: China's Protection of Overseas Chinese during the Late Ch'ing Period, 1851-1911 (Si ngapore: Singapore University Press, 1986), 36. 
1887, the Ch'ing government sent a delegation to the Netherlands Indies to study the commercial relations between the two countries. ${ }^{55}$

The majority of newcomers (singkeh, totok) were not Hokkien as their predecessors had been, so they profoundly altered the ethnic composition of Java's Chinese community. In addition, the proportion of women among the immigrants was now much higher than in the past (women had simply been forbidden to leave China until then), and this abruptly stymied the acculturation process that had been aided by mixed marriages. Moreover, the new migrants were more politicized than the Peranakan had been, and they renewed the relationship with the fatherland while holding out to the Java Chinese a mirror of their Chineseness.

Those various circumstances led the Peranakan to reconsider both their social and cultural status. It was more and more evident that they had lost most of their culture and identity. A Chinese man from Surabaya who had taken part in a local association's activities to revitalize Chinese ancestral customs is reported to have explained that such an effort was needed "because there was a danger [we] would be absorbed in other communities and disappear." ${ }^{56}$

The situation in China was a cause of worry, too. The two Opium Wars (1839-42), the Taiping Rebellion of the 1850-60s, the disastrous Sino-Japanese War of 1894-95, the Boxers Rebellion (1899-1901), and the dismantling of China by European powers made obvious the weakness of China at a time when the Chinese in Java cherished "the idea of a strong, independent China [that] might afford protection to its overseas subjects." ${ }^{57}$ The humiliation of China on the world stage ${ }^{58}$ echoed the humiliation of the Chinese community within the Dutch Indies. In China, as in the Dutch Indies, the rise of a new nationalist feeling was partly the consequence of the pressure and injustice of Europe's imperialism. $^{59}$

At the end of the nineteenth century, following an economic depression, the Dutch inaugurated their "ethic policy." It was presented-and perhaps experienced by most-as a humanitarian gesture (it aimed at paying a "debt of honor" to the colony), but historians have remarked that this humanitarianism itself was economically motivated. ${ }^{60}$ There was a debt because excesses had been committed; there was a feeling of guilt and there had to be culprits. "Hence, condemnation was conveniently made up, that the Chinese were the 'bloedzuigers der Javanen' [the bloodsuckers of the Javanese]. ${ }^{\prime 61}$ Blaming the Chinese was easy, as Java's exploitative colonial system-of

\footnotetext{
${ }^{55}$ Purcell, The Chinese in Southeast Asia, 441.

${ }^{56}$ Claudine Salmon, "Ancestral Temples, Funeral Halls, and the Attemps at Resinicization in Nineteenth Century Netherlands India," in Sojourners and Settlers, 201.

${ }^{57}$ Lohanda, Growing Pains, 47.

${ }^{58}$ In Purcell's terms: "When with the help of guns and rifles China was opened up to Western trade ..." See Purcell, The Chinese in Southeast Asia, 440.

${ }^{59}$ See Tjoe, Pergerakan Tionghoa di Hindia Olanda, 54-75.

${ }^{60}$ See: J. S. Furnivall, Netherlands India: A Study of Plural Economy (Cambridge: Cambridge University Press, 1939 [reprint, 1967]), 227, 232; Lea A. Williams, "The Ethical Program and the Chinese of Indonesia," Journal of Southeast Asian History 2, no. 2 (July 1961): 35-42; and M. C. Ricklefs, A History of Modern Indonesia since c. 1200 (Basingstoke, New York: Palgrave Macmillan, 2008), fourth edition, 183.

${ }^{61}$ See: Lohanda, Growing Pains, 22; and also Purcell, The Chinese in Southeast Asia, 444.
} 
which the Chinese were among the main agents-had led to the scandalous abuses that many observers had condemned during the course of the nineteenth century. ${ }^{62}$

\section{Identity and Language}

The rise of a Chinese nationalist feeling in the archipelago is also linked to the appearance of the press and printed literature. Newspapers in Malay first appeared in the archipelago in 1856. From the very beginning, the Chinese were among their readers: Soerat Kabar Bahasa Melajoe and Bintang Timor, both published in Surabaya, stated in 1856 and 1863, respectively, that their intended audience included Chinese. ${ }^{63}$ This seems to imply that more Chinese adults were able to read than our knowledge of Chinese education suggests, but print runs were actually very low (below a thousand copies). During the first thirty years, the various journals were managed by Dutch and mainly Indo (European mestizos) editors, but the depression of the $1880 \mathrm{~s}$ provoked a significant mutation. Starting around 1886, Chinese editors became prominent. ${ }^{64}$ Bintang Timor, which began publishing in 1862, was purchased in December 1886 by a Chinese businessman, Tjoa Tjoan Lok, from the bankrupt Dutch firm Gebroeders Gimberg \& Co.- a sale that symbolically heralded the increasing Chinese influence on the press. Newspapers more and more reflected the interests, preoccupations, and opinions of the Chinese community, and the papers constituted a forum that certainly contributed to an enhanced feeling of community. As Tjoe Bou San phrased it, "The civil servants of the Dutch administration liked the fact that there was no public opinion in the Indies. Now a public opinion was born." ${ }^{65}$ Bintang Soerabaia, in which the tale of Hang Thok was published in 1888, was the new name given to Bintang Timor when that journal, on July 15, 1887, became a daily newspaper; it remained in print until $1924 .{ }^{66}$

In the same way, literature written in Malay by Chinese authors (so-called "SinoMalay literature"), which emerged at the same time, contributed to assert a cultural identity by highlighting the wealth of a common cultural heritage. During the last three decades of the nineteenth century, that literature was mostly made up of translations of Chinese works, including many historical novels. ${ }^{67}$

The language used by Chinese authors in both journals and books has been the object of prejudice and controversy. It is the language used in the tale of Hang Thok and it is necessary to explain its cultural implications. The Chinese press developed at a time when the Dutch were both establishing an education system using Malay and

\footnotetext{
${ }^{62}$ See: Purcell, The Chinese in Southeast Asia, 430-33; and Carey, "Changing Javanese Perceptions," 36-38.

${ }^{63}$ John Hoffman, “A Foreign Investment: Indies Malay to 1901," Indonesia 27 (April 1979): 81.

${ }^{64}$ Ahmat Adam, The Vernacular Press, 42.

${ }^{65}$ Tjoe, Pergerakan Tionghoa di Hindia Olanda, 64.

${ }^{66}$ Ahmat, The Vernacular Press, 66. About Tjoa Tjoan Lok and his family background, see Salmon, "La communauté chinoise de Surabaya," 147. A Dutch firm had already published in Semarang the previous year the journal Tamboer Melajoe, which was regarded locally as "the first Sino-Malay journal of Semarang," and the editor in chief of which was a Chinese. See Liem Thian Joe, Rizuaiat Semarang (Dari Djamannja Sam Poo sampe Terhapoesnja Kongkoan) (Semarang-Batavia: Ho Kim Yoe, 1933), 152.

${ }^{67}$ The major references on that literature are the work of Claudine Salmon, including an exhaustive bibliography (Literature in Malay by the Chinese of Indonesia), and a long series of articles, some of which have been collected and translated into Indonesian (see C. Salmon, ed., Sastra Indonesia Awal).
} 
defining the variety of Malay that would be adopted for administrative and school use: a Malay in Latin script, the spelling of which was also much debated. The christening date of this official Malay is marked by the publication, in 1901, of Kitab Logat Melajoe, by $\mathrm{Ch}$. A. van Ophuijsen, the handbook of the new spelling that was immediately enforced in government offices and schools. ${ }^{68}$

On the background of this colonial reflection about the definition and elaboration of a standard Malay to be used across the whole archipelago, Chinese authors made an eminently political choice. It has been said for a long time-and this commonplace is not extinct yet-that the brand of Malay used by Chinese authors was a particular dialect, the so-called "Sino-Malay" (bahasa Melajoe Tjina). In fact, at the time of the development of the Chinese press and literature (the last three decades of the nineteenth century), nobody regarded the language they used as a specific "Chinese Malay." Rather, Chinese authors, publishers, and editors intentionally used the common "low Malay" (bahasa Melajoe rendah). Consider, for instance, the title of a book published in Semarang in 1889 by Boen Sing Hoo: Boekoe Sair Binatang: Landak, Koeda dan Sapi, terkarang dalem bahasa Melaijoe rendah (The animals' ballad: porcupine, horse, and ox, composed in low Malay). This was a known fact at the time: Claudine Salmon quotes a text of the Bataviaasch Genootschap from 1887 and another one by Raden Mas Tirto Adhi Soerjo dated 1910, two impressive authorities, commenting that the Malay used by Chinese authors was nothing other than the Malay currently in use in Java. Lie Kim Hok in the 1880s names this language "Batavia Malay" (Melajoe Betawi). ${ }^{69}$ At the beginning of the 1920s, Chinese authors like Phoa Tjhoen Hoat, Phoa Tjhoen Hoay, and Kwee Kek Beng would use the terms "Melayu Tionghoa" and "Chineesch-Maleisch" ("Chinese Malay"), and a debate would follow about the quality and value of this language, supposed to be exclusive to Chinese authors. ${ }^{70}$

Chinese authors of the late nineteenth century were not only aware of the variety of Malay they were using, they also thought it was the literary medium of the future. Praising, in 1928, the language of writers such as Lie Kim Hok and Gouw Peng Liang, which he regarded as a compromise between "High Malay" or "Riau Malay", unintelligible in Java, and "market Malay" (Melajoe pasar), Kwee Tek Hoay concluded, "we believe that [these Chinese writers'] language will eventually defeat and totally eliminate the Riau Malay or 'Ophuijsen Malay' that is to this day protected by the government."

\footnotetext{
${ }^{68}$ See: A. Teeuw, A Critical Survey of Studies on Malay dan Bahasa Indonesia ('s-Gravenhage: M. Nijhoff, 1961), 34; and Hoffman, "A Foreign Investment."

${ }^{69}$ Lie Kim Hok, Melajoe Betawi, Kitab deri hal perkataän-perkataän Melajoe, hal memetjah oedjar-oedjar Melajoe dan hal pernahkan tanda-tanda batja dan hoeroef besar (Batavia: W. Bruining \& Co., 1884; second ed., Batavia: Albrecht \& Rusche, 1891).

${ }^{70}$ Salmon, Literature in Malay by the Chinese of Indonesia, 180. Claudine Salmon sketches the history of the debates regarding this topic in: "La notion de 'sino-malais' est-elle pertinente d'un point de vue linguistique?" Archipel 20 (1980): 177-86, English translation in Salmon, Literature in Malay by the Chinese of Indonesia, 115-22. Dede Oetomo gives details about the spelling of the relevant Low Malay in: "The Chinese of Indonesia and the Development of the Indonesian Language," Indonesia, special issue, 1991: 53-66.

71 “... dan kita pertjaja achirnja bakal kalahken dan moesnaken sama sekali bahasa Melajoe Riouw atawa Melajoe Ophuijsen jang sekarang masih dilindoengken oleh Governement," quoted by Salmon, "La notion de sino-malais," 179.
} 
This is a battle they were to lose, but what matters here is that Chinese authors of the late nineteenth century claimed the validity of the language they had chosen, which was "actually a Malay spoken in cities and towns of Java by all ethnic groups, Javanese and Dutch as well as Chinese, and distinct from the Malay of Sumatra that was gradually introduced by Balai Pustaka's civil servants. ${ }^{72}$ The chosen language was thus a variety of Malay that was not peculiar to the Chinese but was certainly, inside Peranakan society, an identity marker. This Malay was a written language, different from oral varieties, especially the so-called "market Malay"; it was the language common to the various Chinese groups (Peranakan as well as Totok, Hokkiens as well as Hakkas and others). The Peranakan were part of the small minority in the Indies whose first, or even sole, language of communication was Malay, while we know that the Totok learned it quickly. Malay was therefore the language of communication among the various Chinese groups. In electing Melajoe Betawi as a written language, they were simply choosing the language that was familiar to them in daily life. By doing so, they cut themselves off from the Malay literary tradition (the so-called "Malay literature" going back to the fourteenth century) that was, indeed, foreign to most of them. They were writing in a language without tradition, the literary norm of which they were creating.

The care taken by Chinese authors of their literary language is nowhere more evident than in the grammar book published by Lie Kim Hok in 1884, with the title: "Batavia Malay: Treatise on Malay Words, the Analysis of Malay Sentences, and the Use of Punctuation and Capital Letters." ${ }^{73}$ The sole other Indonesian intellectual who devoted a book to the Malay language in the nineteenth century is Raja Ali Haji, whose Bustan al-Katibin was written in Riau in the 1850s. It would be interesting to compare the two books in detail. While Raja Ali Haji painfully applies Arabic categories and linguistic vocabulary to the Malay language, Lie Kim Hok, certainly influenced by S. Coolsma, makes use-much more convincingly —of the Dutch linguistic approach and creates an interesting terminology for his own needs. ${ }^{74}$

\footnotetext{
${ }^{72}$ Ibid., 186. Ironically, after his death in 1912, Lie Kim Hok was dubbed "the father of the Sino-Malay language."

${ }^{73}$ Lie Kim Hok, Melajoe Betawi. See also Denys Lombard, "La Grammaire malaise de Lie Kim Hok (1884)," in Langues et techniques, Nature et société, ed. J. M. C. Thomas and L. Bernot (Paris: Klincksieck, 1972), vol. II, 197-203.

${ }^{74}$ See: Raja Ali Haji, Bustan al-Katibin, diselenggarakan oleh Hashim bin Musa (Kuala Lumpur: Yayasan Karyawan, Karya Agung series, 2005); Harimurti Kridalaksana, "Bustanul-Katibin dan Kitab Pengetahuan Bahasa: sumbangan Raja Ali Haji dalam ilmu bahasa Melayu," in Tradisi Johor-Riau: Kertas Kerja Hari Sastera 1983 (Kuala Lumpur: Dewan Bahasa dan Pustaka, 1987), 70-83; Nico Kaptein, “Arabic Influences on Malay Linguistics," in History of Language Sciences, ed. S. Auroux et al. (Berlin, New York: Walter de Gruyter, 2000), 335-36; and Hashim Hj. Musa, "Raja Ali Haji of Riau as the Pioneer in Establishing Islamic Scholarly Tradition of Language Studies in the Malay World Based on His Bustan al-Katibin and Kitab Pengetahuan Bahasa," Jurnal Filologi Melayu 10 (2002): 65-75. Raja Ali Haji has also written a sketch of Malay grammar as a preamble to his Kitab Pengetahuan Bahasa, written in 1859 and first published in 1928. See Raja Ali Haji, Kitab Pengetahuan Bahasa, yaitu kamus logat Melayu Johor Pahang Riau Lingga, ed. R. Hamzah Yunus (Pekanbaru: Proyek Penelitian dan Pengkajian Kebudayaan Melayu, 1987). There is actually another nineteenth-century Malay book devoted to the Malay language, and an interesting one, too, for that matter-the Kitab Pemimpin Johor, by Muhammad Ibrahim Munshi, the son of Abdullah Munsyi, written in 1871-but it is entirely devoted to the script and the presentation of texts, and does not say a word about morphology and syntax. See: Muhammad Ibrahim Munshi, Kitab Pemimpin Johor, pada menyatakan pengetahuan bagi penulis yang menghendaki sempurna (Singapura, n.p., 1878, Jawi; second ed., 1895); Noor Azah bte Ismail, "Pemimpin Johor: suatu analisis" (BA thesis, Jabatan Pengajian Melayu, Universiti Malaya, 1992); and Kaptein, "Arabic Influences on Malay Linguistics," 336. I regard as
} 


\section{Tiong Hoa Hwe Koan}

Another way by which the Chinese in the Indies endeavored to reform their cultural practices and to revitalize their ancestral culture in the mid to late nineteenth century was the creation of collective temples for ancestor worship and associations for the proper conduct of weddings and funerals, particularly the Hokkien Kong Tik Soe (Temple of the Merits of Fujian), opened in Surabaya in 1864, and the Hokkien Kong Soe (Fujian collective ancestral temple), opened in Makassar in 1868. Initiatives of this kind were motivated by a desire of re-sinization in order to restrain Chinese assimilation into Indonesian society, but they were limited to the Hokkien community, to the exclusion of the Hakkas, Teochius, and others. ${ }^{75}$ On a quite different level, the wealthy Chinese of Batavia created in 1875 an exclusive Chinese-members-only club, called the Societet Betawie, which was modeled on the European clubs Harmonie and Concordia. The Chinese of Semarang created their own club, Boen Hian Tong, the following year. ${ }^{76}$

Another of these associations, one which would have exceptional repercussions, was the Tiong Hoa Hwe Koan (THHK, Chinese Association), created in Batavia in March 1900 by a group of twenty persons, in a spirit of unification. The original Malay text of the association's statutes seems to have disappeared, but their contents, known from a Chinese translation, have been summed up as follows:

Those statutes are divided in four parts: the first aims at revitalizing the links between the Batavia Chinese (Hakkas and people from Fujian) and the fatherland, particularly by reviving Chinese customs and diffusing imperial teachings; the second extols a return to Confucius teachings, the building of a temple in his honor, and the establishing of a calendar starting with the date of his birth; the third aims at uniting the Chinese community, harmonizing the relations between the various groups, developing contacts, developing practical knowledge among adults as well as intellectual capacities among children, thanks to a modern teaching in Mandarin that would teach Oriental as well as Occidental knowledge; the fourth envisions charity action, the distribution of books, the publication of a journal in Chinese, and the defense of the interests of the Chinese nation in the colony. ${ }^{77}$

In a letter addressed a few months later (in July 1900) "to the entire Chinese nation," in the name of the members of the association, its president, Phoa Keng Hek, expressed the aims of Tiong Hoa Hwe Koan, starting like this: "Considering that among us, the Chinese here, many are those who do not know the most perfect and useful teachings and instructions of Confucius (Khong $\mathrm{Hu} \mathrm{Cu}$ ), we, twenty people,

\footnotetext{
"Indonesian intellectuals" all writers who contributed to an intellectual discourse in Malay. As such, Lie Kim Hok is as much an Indonesian intellectual as Nuruddin al-Raniri, who is unanimously regarded as one of the brightest luminaries of Malay literature.

${ }^{75}$ See: Salmon, "Ancestral Temples," 183; and Salmon, "La communauté chinoise de Surabaya," $159-64$.

${ }^{76}$ See: Ahmat, The Vernacular Press, 62; and Liem Thian Joe, Riwoajat Semarang, 138.

${ }^{77}$ Salmon and Lombard, "Confucianisme et esprit de réforme," 393. The cover of a book entitled Peratoeran dari Pakoempoelan "Tiong Hoa Hwe Koan" di Batawi (Batavia: Hoa Siang In Kiok, 1905) is reproduced in Benny G. Setiono, Tionghoa dalam Pusaran Politik (Jakarta: TransMedia, 2008), 318, with the following caption: "Statutes of the THHK which were printed and distributed among its members in 1905."
} 
have agreed to create an association named Tiong Hoa Hwe Koan." ${ }^{78}$ This is followed by the aims of the association, mainly about customs and education, with, again, a strong emphasis on Confucius's teachings.

When analyzing various pan-Chinese associations, Lea Williams remarked that the financial means of the Chinese played a large role in these associations' success, but that a perhaps more important reason for their success was the political and social pressure that the colonial government imposed on the Chinese community: "Dutch policy was a constant reminder to the mass of Chinese that there was no direction in which to turn their energies but inward." ${ }^{79}$ The exceptional success of THHK, as compared to that of other associations, is mainly due to its nationalist spirit, namely, to the fact that the founders could think and write "we, the Chinese here" (kita, orangorang Tjina di sini) in a message addressed "to the entire Chinese nation" (kapada sekalian bangsa Tjina). It is significant that this initiative came from the Peranakan community. In 1933, in his excellent history of Semarang's Chinese community, Liem Thian Joe underlined this rise in a nationalist spirit: "While the South Seas Chinese had for centuries kept a cold heart towards their home country, at that moment the seed of love for their home country sprouted and they started to feel as one nation, unique and sharing the same fate." ${ }^{80}$

The impact of the THHK was tremendous. It successfully fostered a feeling of national consciousness among the Chinese, helped regulate customs regarding weddings and funerals, contributed to improving relations among the various ethnic Chinese groups, gave rise to the creation of efficient chambers of commerce, and, most importantly, managed to create a brand new system of modern education.

The success of the THHK is also obvious in the appearance, in 1901-03, of new Malay journals devoted to its cause: Perniagaan, in Batavia; Ho Po, in Buitenzorg; Li Po, in Sukabumi; Warna Warta, in Semarang; Sien Po and Taman Pewarta, in Sukarata; and Loen Boen and Pewarta Soerabaia, in Surabaya. ${ }^{81}$

It has been suggested that similar associations were created in imitation of the THHK, including one for Arabs, Djamiat'ul Chair, in 1905; for the Javanese, Boedi Oetomo, in 1908; and for Moslem merchants, Sarekat Dagang Islamijah, in $1909 .{ }^{82}$

\section{The Early Rise of Confucianism}

The THHK's insistence on Confucius teachings as the basis of the restoration of Chineseness is somewhat surprising, as the presence of Confucianism in that society is not conspicuous. It was only a few years before the creation of the THHK that a biography of Confucius and the translation of a few of his works into Malay had been

\footnotetext{
${ }^{78}$ Nio, Riwajat 40 Taon Tiong Hoa Hwe Koan, 201.

${ }^{79}$ Williams, Overseas Chinese Nationalism, 112.

80 “... kapan hatinja pendoedoek Tionghoa di Laoetan Kidoel sedari berabad-abad lamanja tinggal dingin terhadep marika poenja tanah aer, itoe koetika moelai bersemi ia orang poenja bibit katjinta'an pada tanah aernja dan moelai merasa sebagi satoe bangsa, jang satoenggal dan sanasib" (Liem Thian Joe, Riwajat Semarang, 174).

${ }^{81}$ See: Salmon, Literature in Malay by the Chinese of Indonesia, 31; and Ahmat, The Vernacular Press, 75.

82 See: Lohanda, Growing Pains, 172; and Ahmat, The Vernacular Press, 85.
} 
published in the archipelago. The biography, in 1897, was the work of Lie Kim Hok, ${ }^{83}$ as was the first translation (1886). ${ }^{84}$ Three of the Four Books ("The Great Learning," "The Doctrine of the Mean," and "The Analects" ${ }^{85}$ ), translated by Njio Tjoen Ean, a Chinese officer, appeared in Ambon in three volumes in 1897-99. Then another translation by Tan Ging Tiong and Yoe Tjai Siang of the first two books was published in Sukabumi in $1900 .{ }^{86}$ Finally, the "Book of filial Piety," translated by Lie Kim Hok and Khoe Siauw Eng, was also published in Sukabumi in $1900 .{ }^{87}$

This represents a remarkable wave of publising activity over a relatively short period (fifteen years only), in Ambon as well as in various cities in West Java. This unexpected surge of Confucianism has been systematically viewed as a sequel to a similar movement in China at about the same time that is associated with the person of Kang Youwei. ${ }^{88}$ This scholar, author of a "socialist utopia" for the entire world, ${ }^{89}$ is no less a visionary than Hong Xiuquan, the instigator of the Taiping rebellion. In 1898, Kang Youwei suggested to the emperor Guangxu that he proclaim Confucianism as the state religion, together with a whole program of reforms. ${ }^{90}$ The emperor eventually issued a series of decrees that were supposed to transform the Chinese government and society in the most spectacular way. The scope of this movement was as ambitious as the Meiji reform had been three decades earlier. However, this initiative is known today as the "Hundred Days of Reform" because, after only a hundred days, the empress dowager Cixi seized power and condemned her nephew, the emperor, to house arrest, and brought the reform movement to a crashing end. The reformers were prosecuted, but Kang Youwei managed to escape and eventually visited Singapore and even Java a few years later.

There does not seem to be, however, any concrete link between the revival of Confucianism in Indonesia and the Hundred Days of Reform, especially if we consider that some of the above-mentioned Indonesian translations and biography of Confucius came before the Hundred Days of Reform. Furthermore, Claudine Salmon has shown that other manifestations of a Confucian revival took place in Surabaya even earlier.

${ }^{83}$ Lie Kim Hok, Hikajat Khong Hoe Tjoe (Batavia: G. Kolff, 1897). Salmon and Lombard, "Confucianisme et esprit de réforme," 382-83, give a summary of this book.

${ }^{84}$ Lie Kim Hok, trans., Pek Hauw Thouw (A hundred cases of filial piety) (Bogor: n.p., 1886). Pek Hauw Thouw was also translated by Tjiong Bo Seng in Batavia in the same year (1886).

${ }^{85}$ Taij Hak [The Great Learning] (Ambon: n.p., c. 1897); Tiong Iong [The Doctrine of the Mean] (Ambon: Ambonsch Drukkerij, 1898); and Siang Loen [The Analects] (Ambon: Ambonsch Drukkerij, 1899).

${ }^{86}$ Tan Ging Tiong and Yoe Tjai Siang, trans., Kitab Tai Hak, Tiong Yong, disalin dalem bahasa Melajoe (Soekaboemi: Soekaboemische Snelpersdrukkerij, 1900).

${ }^{87}$ On these translations, see: Suryadinata, "Confucianism in Indonesia, 37; Coppel, "The Origins of Confucianism, 181; Salmon, Literature in Malay by the Chinese of Indonesia, 195, 230, 261-62, 317, 371-72; and Salmon and Lombard, "Confucianisme et esprit de réforme," 380-83. Charles A. Coppel, "Yoe Tjai Siang: Portrait of a Syncretist," in Coppel, Studying Ethnic Chinese in Indonesia, 279-90, gives a fascinating portrait of Yoe Tjai Siang, a visionary character typical of the stakes of the period, who attempted to reconcile Confucianism, Christianity, and Camille Flammarion's scientism.

${ }^{88}$ See, for example: Nio, Riwajat 40 Taon Tiong Hoa Hwe Koan; Suryadinata, "Confucianism in Indonesia"; Coppel, "The Origins of Confucianism"; and Coppel, "Is Confucianism a Religion?"

${ }^{89}$ Marianne Bastid, "Kang Youwei [K'ang Yeou-Wei] (1858-1927)," Encyclopædia Universalis online, http: // www.universalis.fr/encyclopedie/kang-youwei-k-ang-yeou-wei/, accessed December 12, 2014.

${ }^{90}$ The role of Kang Youwei has lately been denied by an historian; see Luke S. K. Kwong, "Chinese Politics at the Crossroads: Reflections on the Hundred Days Reform of 1898," Modern Asian Studies 34, no. 3 (July 2000): 663-95. 
Those are the work of a member of an old and respected Surabaya family, Tjioe Ping Wie, who had studied in China. When back in Surabaya, around 1880, he distributed among the Chinese community a short pamphlet on Confucius, which he had had printed in Shanghai. ${ }^{91} \mathrm{He}$ also opened a school under the patronage of Confucius and he calculated and produced a calendar based on the Master's birthdate, which was printed and sold, and dates from which appear on two local stone inscriptions of the 1880s. ${ }^{92}$ Later on, in 1899, still in Surabaya, Chinese merchants and notables transformed the Wenchang temple, which had been dedicated to the God of Literature three years before, into the Boen Bio, which was dedicated to Confucius. ${ }^{93}$

One difference between the Confucian movement in Batavia, on the one hand, and that in China and Singapore, on the other, is that the former was not religious. While Kang Youwei had a conception of Confucianism as a religious and cultural system comparable to established universal religions, ${ }^{94}$ and Lim Boon Keng founded the Confucian religious society (Kong Kauw Hwe) in Singapore, the founders of the THHK had mainly social projects in mind. No evidence has been demonstrated so far of any direct influence from the Confucian movement in China over the similar movement in Java. Neither does the movement in Java seem to be directly related to the events in Singapore, where Confucian temples and schools as well as a Confucian religious society were created at the initiative of Lim Boon Keng and Song Ong Siang in the very last years of the nineteenth century. ${ }^{95}$ However, there is one international connection that still needs to be investigated, and that is the one with Japan. Salmon and Lombard have disclosed specific links between the Confucian revival in Java and similar, anterior movements in Yokohama. ${ }^{96}$ The Chinese of Yokohama created in 1873 an association called Zhonghua huiguan (exactly like Batavia's THHK), with the aim of bringing together the Chinese inhabitants of the city without consideration of their regional or ethnic origin. Furthermore, a Confucian Association (Siwen hui) was created in Yokohama in 1887, which served as a model for a similar one created in Surabaya at the end of the century. Contacts between the Chinese elites of Yokohama and Batavia are proven, and Salmon adds that the Surabaya association was probably created by Chinese merchants from Yokohama or Japanese merchants residing in Surabaya. ${ }^{97}$

\footnotetext{
${ }^{91}$ Salmon, "La communauté chinoise de Surabaya," 162.

${ }^{92}$ See: Claudine Salmon, "Was the Confucius Chronology First Applied in China or in the South Seas?" Haiyangshi yaniu, Studies of Maritime History 6 (2014): 266-84; and Salmon and Lombard, "Confucianisme et esprit de réforme," 400.

${ }^{93}$ Salmon, "La communauté chinoise de Surabaya," 162. Boen Bio is Hokkien for Wen Miao, "temple of culture."

94 See, for example, Kwong, "Chinese Politics at the Crossroads."

${ }^{95}$ See Yen Ching-hwang, "The Confucian Revival Movement in Singapore and Malaya, 1899-1911," Journal of Southeast Asian Studies VII, 1 (March 1976): 33-57. For Williams, Overseas Chinese Nationalism, 44, the THHK was created as a sequel of the Singapore movement. There must have been personal contacts (Kang Youwei did not visit Indonesia before 1903, but we know, for instance, that Tan Gin Tiong met Lim Boon Keng in Singapore in December 1899; see Coppel, "The Origins of Confucianism," 261), but the milieu was not the same and the pace of the respective movements was different, too.

${ }^{96}$ Salmon and Lombard, "Confucianisme et esprit de réforme," 394, 396.

${ }^{97}$ Claudine Salmon, "Confucianists and Revolutionaries in Surabaya (c. 1880-c. 1906)," in Chinese Indonesians: Remembering, Distorting, Forgetting, ed. Tim Lindsey and Helen Pausacker (Singapore: ISEAS, Clayton: Monash Asia Institute, 2005), 133.
} 
In Batavia, however, the social manifestation of a Confucianist religion does not precede the twentieth century. There are clear indications of this-for example, the 1890 s publications relating to Confucius mentioned above make no allusion to a religion; in Java, there is no temple or shrine dedicated to Confucius; ${ }^{98}$ and the few testimonies we have of the teaching of Confucius's philosophy in Chinese schools make no reference to religion, either. The main point here is that the statutes of the THHK mention Confucius's doctrine as a fundamental basis for the reformation of some customs, but not as a religion. Nio Joe Lan's historical sketch of the THHK contains among its appendices two documents, the comparison of which sheds a light on this matter. The first is the July 1900 letter sent by the THHK executive committee to all members of the "Chinese nation." totally foreign to religion: they are "teachings" (pengadjaran) or "teachings or advices" (pengadjaran atawa pitoewa), and they are "noble, beautiful, and useful" (moelia, indah, berfaedah); the doctrine of the Master is "appreciated and revered in the whole of China" (disoekai dan ada terdjoendjoeng di seäntero Tanah Tjina); and the word Nabi (Prophet) is used, but there is no allusion whatsoever to a religion or even a cult. The second document is an open letter to a reader (Lauw Tjiang Seng) who asked about the religion of the Chinese and whether Confucianism is a religion. The letter, written by a four-member ad hoc commission that included Lie Kim Hok, is dated December 20, 1902, and was published in $\mathrm{Li}$ Po in February $1903 .^{100}$ The committee explained that Confucianism is the true religion of the Chinese, even though some may have adopted other religions as well (Buddhism and Taoism, even Islam for Chinese in Java) and devised syntheses of multiple belief systems. This answer does not refer to any fact or event that would locate a Confucian religion in a historical setting; it does not pretend that this religion has a history (there is no evolution, no major date, no debate; the committee's aim was to translate Confucius's philosophical doctrine into religious terms). On the contrary, the answer gives the impression that this reflection is absolutely new, prompted by the reader's question.

The juxtaposition of these two documents in the book leads to the conclusion that the conception of Confucianism as a religion, at least in the mind of the founders of the THHK, was born at that moment, in late 1902. Charles Coppel has shown that it is the published debates between the missionary L. Tiemersma and more than twenty "Confucianists" that eventually lead the latter to conceive of and formulate Confucius's teachings as a religion in opposition to, or at least by comparison with, Christianity's teachings. ${ }^{101}$

There are exceptions. The dedication in 1899 of a Surabaya temple (Boen Bio) to Confucius clearly indicates that a Confucius cult existed at the turn of the century. Moreover, short quotations cited by Coppel show that, for Tan Gin Tiong and Yoe Tjai Siang, the books Tai Hak and Tiong Iong are religious texts. ${ }^{102}$ In the emphatic and syncretic prose of Yoe Tjai Siang, who, incidentally, was a Christian, this does not

\footnotetext{
${ }^{98}$ Coppel, "The Origins of Confucianism," 182.

${ }^{99}$ Nio, Riwajat 40 Taon Tiong Hoa Hwe Koan, Appendix A, 201-3.

100 "Agama Tjina"[Chinese religion], Li Po 3, no. 97 (February 14, 1903), Appendix F, $213-19$.

${ }^{101}$ Coppel, Studying Ethnic Chinese in Indonesia, 303-8. The debates started in May 1902, in the columns of the journals $L i$ Po and Bentara Hindia.

${ }^{102}$ Ibid., 282-86.
} 
mean that Confucianism is a religion, but, rather, that Confucius's doctrine, together with the Bible, is part of a corpus containing the Truth: truth about God, man, and the universe. These two examples-the temple and the books-show that the idea of a Confucian religion was already present in the mind of some individuals at the very end of the nineteenth century. For the Batavian elite of the Peranakan, however, it seems likely that the idea of a Confucian religion has been elaborated and formulated for the first time precisely in the second half of 1902.

The relevance of the early rise of Confucianism in the late nineteenth century to the story of Hang Thok is twofold. First, Confucianism was chosen, in 1900, precisely because it was not a religion. Had the founders of the THHK chosen Buddhism or Taoism, or a China-oriented nationalism, as the basis for their action, they would not have provoked a Pan-Chinese movement that was as successful as what THHK became. Second, among the aims proclaimed at the time of the foundation of the THHK, the promotion of Confucianism was the least successful of all because of the rise of political nationalism in the wake of the 1911 Revolution and because, in the early decades of the twentieth century, the Totok took the lead of the Pan-Chinese movement.

\section{The European Challenge}

The impact of European modernity had indeed a major role. The sudden activity of a certain Chinese elite in Java around Confucius in the last years of the nineteenth century and the choice of Confucianism as the basis of the THHK are somewhat surprising. One historian has even interpreted this development as being disengenuous: "To dignify their nationalism with a cover of antiquity, to conceal its Western inspiration, and to put forward a respected and familiar symbol, the Chinese of Netherlands India, though not fully conscious of their motivations, resurrected Confucius." ${ }^{103}$ But this viewpoint is contradicted by the evidence. The election of Confucius's teachings as the nationalist movement's philosophical and spiritual basis may not have been explicitly articulated, but it was profound and had precise causes, one of which was the challenge of Europe's scientific, technological, and intellectual domination in the world. The political power and technological superiority of the Dutch was an everyday sight throughout Java. Signs that the local population, including the Chinese, were being Westernized became more and more apparent.

In the early 1860s, several protestant missionaries were sent to West Java (Priangan) by the Dutch Missionary Society (Nederlandsche Zendingsvereeniging) to convert the locals and translate the Bible into Sundanese. Christian Albers and D. J. van der Linden were the first to arrive, and were soon joined by A. Dijkstra, A. Geerdink, S. Coolsma, and L. Tiemersma. They opened schools in Buitenzorg, Cianjur, Indramayu, and Cirebon. Instruction was sometimes given in Sundanese, but mainly in Malay. ${ }^{104}$ Considering the difficulty that the Chinese encountered in accessing any sort of education, Chinese families sent their boys to those Dutch missionary schools. Some of the most prominent figures of the Confucian movement were among those-including

\footnotetext{
${ }^{103}$ Williams, Overseas Chinese Nationalism, 54.

${ }^{104}$ Coppel, "From Christian Mission to Confucian Religion."
} 
Phoa Keng Hek (the first president of the THHK), Lie Kim Hok (the famous writer), and Yoe Tjai Siang (translator of Confucius's works and editor of $L i$ Po), who were fellow pupils at Coolsma's school in Bogor in the late 1860s. It is no coincidence that the two promoters of the Confucian movement in Singapore-Lim Boon Keng and Song Ong Siang—studied in England and were members of the Presbyterian Church. ${ }^{105}$

Lie Kim Hok's experience is typical of the impact of that education. Born in 1853 in Bogor, he was taught to read Malay and Sundanese by his father, then briefly attended Albers's school in Cianjur. When his family moved back to Bogor, he attended the local Chinese school, where he was taught to read the Chinese classics, pronounced in Hokkien. But after three years he was still unable to read properly, to the effect that, during his later carrier as a writer and translator, he had to ask a better-educated friend to help him when confronted with Chinese sources. At the age of thirteen, he transferred to the school that the Dutch mission had just opened in Bogor. He would remain associated with that school for eleven years, first as a pupil and then as an assistant to Coolsma and later to van der Linden, during which time he followed a course about Christianism, learned Dutch, operated the mission's printing press, and wrote a few handbooks for children. When van der Linden died, Lie Kim Hok bought the press and started a business as a printer (he published the short lived Pembrita Betawi), but had to sell the press back two years later. After many hardships, in 1890, at the age of forty-six, he obtained a stable position in commerce. From then until his death in 1912, he devoted his free time to writing and translating. A very talented and prolific author, he produced a vast quantity of work, including translations from the Dutch and Chinese, and became famous during his life time. He was among the founders of the THHK and wrote a few books about the life and teachings of Confucius. ${ }^{106}$

It would be interesting to make a thorough comparison of Lie Kim Hok and Abdullah Munshi. With a lapse of some fifty years, in two different but in some ways similar places (West Java and Singapore), both underwent a strong European influence, worked for Christian missionaries, were among the first and enthusiastic adepts of printing in Southeast Asia, acted as interpreters of certain aspects of Western culture to their fellow citizens, paid particular attention to the Malay language, and became famous writers. On the other hand, the differences between the two are, of course, considerable. Here, like in the case of Raja Ali Haji, above, Lie Kim Hok, as an eminent figure of the Peranakan community, is on a par with a no less eminent figure of the Muslim Malay cultural elite.

Not many Chinese received a Dutch education, but the Chinese elite at large was nevertheless much aware of European might in every domain. The choice of Confucius as the basis of a modern national ideology was partly a reaction against it. "Exposure to Christianity led some Chinese to look to the ancient cultural heritage of their homeland for reassurance that morality was not a European innovation in Asia. To many Chinese, after all, the acceptance of Christianity implied a recognition of Western cultural superiority. ${ }^{107}$ Confucianism, which was so praised in Europe (Lie Kim Hok's

\footnotetext{
${ }^{105}$ See Lohanda, Growing Pains, 52.

${ }^{106}$ See: Coppel, "The Chinese Minority," 49-50; and Salmon, Literature in Malay by the Chinese of Indonesia, $228-32$, including an exhaustive list of his writings.

${ }^{107}$ Williams, Overseas Chinese Nationalism, 173.
} 
biography was mostly based on European sources), offered an ideology of universal dimension. Composing a versed biography of Confucius in 1924, H. Brightson wrote: "While Europe has a prophet in the person of Jesus, we in China have the prominent figure of Khong Hoe Tjoe." 108 "Far from being the pure and simple transference of the traditional teachings of the Sage as they could be found in the 'Classics,' the Confucianism of the Chinese communities in Insulindia mostly appears to us as a clever Sinicization of the innovating principles imported from the West." 109

\section{Confucianism and Peranakan Culture}

The publication of Hang Thok's tale in a Malay schoolbook in Batavia as early as 1878 presents a conundrum; it goes against what has been said above about the history of Confucianism in Indonesia as well as the history of Chinese education in Java. That publication is not explained by the revival of Confucianism around the 1890s; on the contrary, it helps to explain that revival.

Studies regarding the development of Confucianism in Java are devoted to occasional events-for example, the building of temples, creation of associations, and publication of books-but they say little about the place of Confucianism in daily life, whether familial or public, of the Chinese community. Those events should not be regarded as the birth of an interest in the teachings of Confucius, but rather as a wish to deepen the existing knowledge and understanding of those teachings in an effort of re-sinization.

This is what our Malay schoolbooks suggest. According to a seventeenth-century Dutch observer, all that Chinese boys learned in Chinese schools "was the use of the abacus, to get by rote the Four Books-the Annalects, the Doctrine of the Mean, the Great Learning, and Mencius-and to write a conventional letter." Victor Purcell, who quotes this remark, adds that "The curriculum in a Batavia Chinese household or school was probably not a whit different in the time of the first Captain Bencon in 1620 from what it was in 1890." ${ }^{110}$ Such an extrapolation is somewhat justified by another testimony which, two centuries later, offers similar information by way of the description of Chinese schools in 1879:

The teacher is seated at a separate table standing near the wall facing the entrance door. On this wall, at a certain height, hangs a scroll of red paper bearing an inscription in Chinese characters: "The most holy master Khong-hoe-tsoe [Confucius]." Underneath it, a high, long, and very narrow table right against the wall supports a pot filled with ashes into which joss sticks are stuck. [...] When entering the school, the pupil walks respectfully towards the master, joins his

\footnotetext{
${ }^{10 s}$ Brightson-Kediri, Sair Pengidoepan Nabie Khong Hoe Tjoe, stanza 7.

${ }^{109}$ Salmon and Lombard, "Confucianisme et esprit de réforme," 402.

${ }^{110}$ Purcell, The Chinese in Southeast Asi, 452, giving as his source the account of the Dutch surgeon Wouter Schouten, who visited the Indies around 1660. See Wouter Schouten, Wouter Schoutens Oost-Indische voyagie (Amsterdam: Meurs, 1676) and French translation, Voiage de Gautier Schouten aux Indes orientales, commencé l'an 1658 \& finil'an 1665 (Rouen: J. B. Machuel le Jeune, 1725).
} 
hands and bows in front of the inscription devoted to Confucius; then he salutes the master in the same fashion, and finally gets quietly to his seat. ${ }^{111}$

And further on:

In all schools, pupils are given the same books. Those are what people regard as the Chinese classics. [...] The books given to study to Chinese boys are those called The Four Books, two of which are attributed to Confucius himself, another one contains the dialogues and sayings of the most venerated of all philosophers, and the fourth one contains the lessons of his a little less famous disciple, Mencius. Those books may be regarded as the moral code of the Chinese. ${ }^{112}$

1879 is the year of this description, while the first known publication of Hang Thok's tale dates from 1878. At that time Confucianism was not yet regarded as a religion, but we have various pieces of evidence that Confucian values were at the core of Peranakan culture. Filial piety is among the most important of these values: defined as love, respect, and veneration of the elders, both dead and alive, filial piety is at the heart of a code of behavior giving priority to the perenniality of the family and of family values. ${ }^{113}$ The most prominent Chinese families in Surabaya (the Han, Tjoa, and The families), studied by Salmon, with their concern for genealogy (the Han family traces its ancestors back to the sixteenth, twelfth, and even the eighth centuries), ancestral temples, and the principle of filial piety, are a good example of the importance of Confucianism in Peranakan culture. ${ }^{114}$

Talking about the foundation of the THHK, Nio Joe Lan remarked: "There is no reason to wonder why people have decided to rest on the precepts of Confucius, because he has forever until now been regarded as the Great Master of the Chinese, whose doctrine has been valued outside China as well." ${ }^{115}$

The founders of the THHK had probably not used our Boekoe pladjaran during their school years, but they, too, had learned to revere Confucius as the ancestral source of wisdom, as the figure who had bequeathed a guide for proper conduct in society and had become a symbol of the national culture. When confronted with the need to select a Chinese figure as an equivalent of the symbolic figures of Western civilization, it was natural that they should elect the "prophet" Confucius.

\footnotetext{
${ }^{111}$ Albrecht, "Het Schoolonderwijs," 231.

${ }^{112}$ Ibid., 234, 236.

${ }^{113}$ Willmott, The Chinese of Semarang, 204.

114 See: Salmon, "The Han Family of East Java"; and Salmon, "La communauté chinoise de Surabaya."

${ }^{115}$ Nio, Riwajat 40 Taon Tiong Hoa Hwe Koan, 7.
} 


\section{APPENDIX}

The Tale of Hang Thok ${ }^{116}$

Hikajat Wali Tjina Khong Hoe Tjoe jang mengadjar sekalian bangsa Tjina

aken mengenali soerat soerat Tjina

Tjerita doeloe kala ada wali Tjina bernama Khong Hoe Tjoe. Maka pada soewatoe hari itoe wali ada niat aken pigi, mengadjari orang di blakang kota Lokok negeri bangsa Islam, laloe dia naik soewatoe kreta dengen teriring pada sekalian moerid moeridnja (anak sekolahnja) satelah sampe setengah djalan, dia bertemoe 4 anak anak ketjik lagi itoe anak bermain main serta bergoejon pada temennja maka jang 1 menoempoek noempoek batoe dia kento kento ${ }^{117}$ seperti benteng boeat menjeseki djalan itoe dan wali Khong Hoe Tjoe serta dapet melihat begitoe lantas brentiken, kretanja dengen menanjak pada anak jang tida toeroet bergoejon itoe.

He! kenapa kau satoe anak tiada maoe toeroet temen temenmoe bermain.

Dia orang bermain trada ada bergoena bolih bikin pitjah badjoe dan bikin kotor tjelana djadi hamba takoet pada hamba poenja Emak dan bapak jang ada di roemah kaloe hamba poenja tjelana badjoe sampe dapet pitjah temtoe hamba poenja Emak bapak marah pada hamba dan laginja bikin soesah pada hamba poenja Emak bapak misti beliken lagi hamba poenja pakean dan hamba djoega dapet tjape hamba poenja badan; itoe goejon trada goenanja mendjadi hamba tida maoe toeroet.

Wali Khong Hoe Tjoe, dengen begitoe lantas berkata kaloe begitoe kenapa kau bikin ini benteng bentengan ada di tengah djalan sini lekas kau bolih pigiken ${ }^{118}$ kita poenja kreta maoe berdjalan.

Anak ketjil mendjawab.

Ja padoeka, hamba poenja ingetan dari doeloe sampe sekarang patoetnja kreta jang njekre ${ }^{119}$ boekannja benteng jang njekre.

Srenta wali Khong Hoe Tjoe, denger itoe anak poenja tjerita'an dia lantas toeroen dari kretanja dengen berkata.

He! kau satoe anak ketjil kenapa kau banjak bitjara poeter poeter. ${ }^{120}$

\footnotetext{
${ }^{116}$ The following text aims to reproduce scrupulously the 1888 Malay version of Hang Thok's tale, including its puzzling punctuation and a few misprints. The story was published in two editions of Bintang Soerabaia (nos. 161 and 163, July 16 and 19, 1888) and signed by "T. T. La." Several variants of the two other available versions (the schoolbook editions, abbreviated as "BP 1884" and "BP 1929"), are mentioned in the footnotes whenever doing so may help our understanding of the 1888 version.

${ }^{117}$ In Javanese, dientho-entho means "arranged neatly and properly" or "built in the shape of"; this is clearly the meaning here.

${ }^{118}$ pigiken, BT 1884: pindaken.

${ }^{119}$ njekre, BT 1884: minggir. The word njekre is unknown, but the meaning is clearly "to move over, give way."

${ }^{120}$ poeter poeter, BT 1884: djoesta.
} 


\section{Mendjawab anak ketjil.}

Ja padoeka manoesia oemoer 3 tahoen bolih pisah Emak dan bapak dan binatang kantjil lahir 3 boelan ${ }^{121}$ soeda bisa lari koeliling di oetan dan ikan lahir 3 hari soeda bisa pelesir di dalam kali jang dalem itoe ada toean allah ta'allah soeda nitahken ${ }^{122}$ begitoe tiada bolih kata hamba bitjara poeter poeter.

Dan srenta wali menanjak.

Ja sekarang kita tanjak kau tinggal di kampoeng mana district apa dan kau Seh ${ }^{123}$ apa namanja siapa dan nama sekolahmoe sekali siapa ${ }^{124}$.

Mendjawab anak ketjil dengen bitjara renda.

Hamba tinggal di pagoenoengan tempat sepi ${ }^{125}$ hamba Seh Hang, bernama Thok, beloen ada nama sekolahnja.

Dan wali berkata lagi.

Kami ada soeka adjak kau bersama sama pelesir, bagimana kau poenja pikiran.

Hang Thok mendjawab.

Ja padoeka djangan ambil mara sebab di roemah hamba misih ada Emak dan bapak saja misti rawati sebab hamba keliwat tjinta sekali pada hamba poenja Emak dan bapak itoe patoet hamba piara dan ada lagi hamba poenja soedara jang toewa patoet hamba misti menoeroet pada dianja dan hamba ada adik jang timoer ${ }^{126}$. patoet hamba mengadjar pada dianja dan di roemah ada singse (meester) ${ }^{127}$ misti hamba beladjar pada itoe meester bagimana hamba bisa sempet mengikoet Padoeka pigi pelesir-pelesir.

Wali berkata.

Ja di dalem kami poenja kreta ada 32 bidji permainan. Tiookie (matjanan) Tjina ${ }^{128}$ kami maoe adjak main pada kau dan kau poenja pikiran pigi mana.

Hang Thok mendjawab.

Djikalaoe bangsa Radja soeka main temtoe negri tida karawatan kaloe mantri perang soeka main temtoe dia poenja barisan tida oeroes kaloe hamba lagi beladjar sekolah hamba bermain temto hamba loepa peladjaran Meester, kaloe orang

\footnotetext{
${ }^{121}$ binatang kantjil lahir 3 boelan, BT 1884: klentji dalem oemoer 3 hari, BT 1929: kelentji lahir 3 hari.

122 nitahken, BT 1884: tentoekan, BT 1929: takdirken.

${ }^{123}$ Seh, BT 1884: She. "She" (xing) is the family name.

${ }^{124}$ This version of the tale, together with the 1888 Malay version, are the only two which mention a school, as the result of a misunderstanding of the term tseu $(z i)$ in the Chinese original. In this context, $z i$ means the adult name that Chinese educated people used to adopt at the age of twenty, but the word also means "character," which may explain the confusion with "school." It is also possible that the source of these Malay versions chose to replace tseu with sekola to be more easily understood. My thanks to Claudine Salmon for this clarification.

${ }^{125}$ pagoenoengan tempat sepi, BT 1929: di desa djelek, tanah hina.

${ }^{126}$ timoer is Javanese for "young," here "the youngest."

${ }^{127}$ singse (meester), BT 1884: Sinshe (goeroe).

${ }^{128}$ Tiookie (matjanan) Tjina, BT 1884: $\varnothing$, BT 1929: bidji Tjoeki.
} 
berdagang soeka main temtoe binasa dia poenja arta dan banda ${ }^{129}$ kaloe boedak soeka main tida woeroeng ${ }^{130}$ dapet rotan dari toewannja kaloe orang tani soeka main temtoe lat dianja bolih boewang widi ${ }^{131}$ maka dari itoe hamba trada niat maoe main.

Wali berkata.

Ja kami soeka adjak kau boeat ngerataken negri ${ }^{132}$ bagimana kau poenja pikiran.

Hang Thok mendjawab.

Doenia trada bolih di rataken ada goenoeng jang tinggi ada laoet jang lebar dan jang dalem orang djoega ada jang berpangkat ada jang berkoeli djikaloe goenoeng tinggi di boeat rata temtoe boeroeng dan binatang di oetan trada ada tempatnja kaloe laoet dan soengi di oeroek itoe ikan dan lain-lain jang idoep di aer misti tinggal di mana, kaloe trada orang jang berpangkat temtoe orang ketjil anak negri trada tahoe salah betoelnja, kapan trada orang koeli temtoe trada ada ketahoean jang mana toeannja, di dalem doenia trada bolih di bikin rata.

Wali menanjak dengen badehi ${ }^{133}$.

Apa kau tahoe di dalem alam doenia poenja isi api apa jang trada ada asepnja, ada aer trada ada ikannja, ada goenoeng trada ada batoenja, ada poehoen trada ada tangkisnja ${ }^{134}$ dan orang laki trada ada prampoeannja dan orang prampoean trada ada lakinja, ada kerebo tiada ada kandangnja ada koeda tiada ada orang jang naik, manoesia bagi mana, bolih bisa djadi penggawa dan bagi mana bolih bisa djadi koeli, di doenja apa jang bisa koerang dan apa jang bisa lebih, dan kota apa jang tida ada pasarnja, dan orang apa jang tiada nama sekolah.

Hang Thok, mendjawab.

Ja Padoeka dari hamba poenja ingetan di hati api konang tiada koekoes ${ }^{135}$, aer soemoer tida ada ikannja, goenoeng tanah tiada batoe, itoe pohon toewa jang soeda berandili ${ }^{136}$ tiada tangkis, orang dewa tiada ada bini, Widodari ${ }^{137}$ tiada ada lakinja, koeda kajoe tiada ada orang jang naik, kerbo tanah tiada kandangnja, orang pinter bisa djadi penggawa, kaloe orang bodo tamtoe djadi koeli, Tjina boelan 10 hari ada pandjang temtoe ada lebih. Tjina boelan 6 hari ada pendek temtoe ada koerang ${ }^{138}$. Kota radja tiada ada pasarnja anak ketjil tiada ada nama sekolahnja.

\footnotetext{
${ }^{129}$ arta dan banda, BT 1884/1929: harta banda.

${ }^{130}$ tida woeroeng, BT 1884: tentoe.

${ }^{131}$ widi, BT 1884/1929: bibit.

${ }^{132}$ ngerataken negri, BT 1884: poekoel nagri, BT 1929: bikin rata negri-negri antero doenia.

${ }^{133}$ badehi, BT 1884: berbade.

${ }^{134}$ tangkisnja, BT 1884: tjabangnja, BT 1929: tangkenja.

135 di hati api konang tiada koekoes, BT 1884: itoe Koenang-koenang berapi tiada asepnja, BT 1929: Api koenang-koenang, tiada ada asepnja. Kukus is Javanese for "smoke."

${ }^{136}$ berandili, BT 1884: Ø, BT 1929: poehoen kering. Certainly an error for brindhil, Javanese for "denuded, bald."

${ }^{137}$ Widodari, BT 1884/1929: bidadari.

${ }^{135}$ Tjina boelan 10 hari ada pandjang temtoe ada lebih. Tjina boelan 6 hari ada pendek temtoe ada koerang, BT 1884: Boelan Tjap Gwe arinja pendek! Boelan Lak Gwe arinja pandjang!, BT 1929: Moesim "Tang" (boelan 10, 11 dan 12 harinja pinda), terbilang tiada tjoekoep! Moesim "He" (boelan ka 4, 5 dan 6 lagi pandjang) terbilang ada lebih!
} 


\section{Ada samboengannja.}

[The second installment ${ }^{139}$ begins here.]

Wali bertanjak lagi.

He! apa kau tahoe langit dan boemi poenja perdjalanan, dan doenia dengen acherat, poenja kapala dan bontot dan jang mana kanan dan jang mana kiri, jang mana loewar dan jang mana dalem, jang mana bapak jang mana emak, jang mana laki dan jang [mana] prampoean, angin dari mana datengnja, oedjan dari mana sangkanja ${ }^{140}$, asep dari mana kloewarnja, awan dari mana datengnja langit dan boemi ada brapa poeloe riboe paal pandjangnja.

Hang Thok mendjawab.

Ja! padoeka dari perdjalanannja doenia, adanja simbilan kali sembilan djadi delapan poeloe satoe, itoe adanja, dari kapala dan boentoetnja doenia dengen Acherat delapan sembilan kali $^{141}$ djadi toedjoe poeloe doewa adanja, dan langit seperti bapak, boemi seperti Emak. Mata hari ada laki, remboelan djadi prampoewan, wetan terseboet kanan, koelon terseboet keri ${ }^{142}$, kaponakan itoe ada sanak loewar, Empektoewa $^{143}$ itoe ada sanak dalem, angin kelihatan dari daon ${ }^{144}$, oedjan dari goenoeng menangis ${ }^{145}$; asep keloear dari atas goengeng, kalemoen ${ }^{146}$ keloear dari tanah, boemi dan langit beriboe riboe keti djaoehnja, wetan, koelon, lor, kidoel, itoe koepingnja ${ }^{147}$, kaloe padoeka koerang pertjaja tjoba padoeka oekoer.

Wali bitjara lagi.

He! kau poenja ingetan lebih sanak ${ }^{148}$ mana, emak bapak sama bini.

Hang Thok mendjawab.

Ja padoeka hamba poenja timbangan Emak bapak ada lebih sanak.

Itoe tempo baroe wali bisa membatoe ${ }^{149}$ djawab.

He! bagimana kau bolih bilang Emak bapak ada lebih sanak dari laki-bini, krana idoepnja tidoer sama sama ${ }^{150}$, teroes sampe mati djoega koeboer satoe badan berdoea, bagimana kau bilang Emak bapak lebih sanak.

${ }^{139}$ T. T. La, Bintang Soerabaia 163, July 19, 1888.

${ }^{140}$ sangkanja, BT 1884: sampenja. Sangka is Javanese for "from, origin."

${ }^{141}$ delapan sembilan kali, BT 1884/1929: delapan kali sembilan.

${ }^{142}$ wetan terseboet kanan, koelon terseboet keri, BT 1929: Wetan terbilang kiri! Koelon terbilang kanan! The Javanese version has: "West is right, east is left."

${ }^{143}$ Empektoewa, BT 1884: Empe (Oewa).

${ }^{144}$ angin kelihatan dari daon, BT 1929: Angin asal dari poehoenan.

${ }^{145}$ oedjan dari goenoeng menangis, BT 1884: Oedjan kliatan dari Kauw Tjhie, BT 1929: Oedjan asal dari oetan loear kota.

${ }^{146}$ kalemoen, BT 1884: halimoen, BT 1929: Pedoet (halimoen).

147 itoe koepingnja, BT 1929: masing-masing ada watesnja, Javanese version: watesipun.

${ }^{148}$ sanak, BT 1929: dekat, Javanese version: ruket. In Javanese, sanak means "close."

${ }^{149}$ membatoe, BT 1884/1929: Ø. The word does not make any sense here, it may be an error for $b a k u$, "mutual, reciprocal." 


\section{Hang Thok mendjawab.}

Ja padoeka jangan ambil mara, orang laki kematian bini, ibarat kreta tiada ada rodanja dibikinken lagi boekan ${ }^{151}$, misih bolih tambah koewat dan tambah baroe lagi tambah kesenengannja, itoe ibarat orang laki bini seperti orang bikin roemah kendati tjagaknja ngerentep, tida ngelawan belandar satoe dan kendati tjendela berdjentrek djentrek tida lawan pintoe satoe dia poenja terang ${ }^{152}$, dan di langit banjak bintang kebiar kebiar trada lawan remboelan satoe terangnja dia poenja tjahja itoe ibarat bapak dan Emak trada bisa abis abis dari ketjinta'annja.

Kamoedian wali Khong Hoe Tjoe, mendengerken bitjaranja itoe Hang Thok, lantas menjegoel ${ }^{153}$ menarik napas sembari berkata.

Hian Tjaij Hian Tjaij [soenggoe pinter soenggoe pinter] ${ }^{154}$ betoel dia satoe anak ketjil tetapi lebih pinter dari orang toea toea semoeanja.

Hang Thok serta lihat wali menarik napas lantas dia bolih tetanjak.

Ja apa jang padoeka soeda kasi badean pada hamba satoe persatoenja hamba soeda bisa mendjawab maka sekarang saja toeroet tetanjak pada padoeka di sini djangan sampe mendjadiken padoeka ampoenja mara hati dan goesar itoe gangsa dan bebek kenapa bisa timboel di atas aer dan dari boeroeng tjangak ${ }^{155}$ soewaranja begitoe kras dan poehoen weringin ketigo rendeng ${ }^{156}$ kenapa dia poenja daon idjo sadja.

Khong Hoe Tjoe mendjawab.

Gangsa dan bebek maka bisa timboel di atas aer sebab dari kakinja lebar lagi pendek dari boeroeng tjangak maka boeninja kras tegal dari lehernja pandjang dan dari poehoen weringin makanja dia poenja daen idjoe rendeng ketiga sama sadja sebab hatinja keras.

Hang Thok menjaoet.

O! boekannja begitoe seperti ikan bisa timboel di atas aer apa kakinja lebar dan pendek dan itoe koeda ${ }^{157}$ dia poenja boeni begitoe kras apa lehernja pandjang lagi itoe poehoen bamboe dia poenja daon rendeng ketiga idoep sadja kenapa tiada ada hatinja.

Dan sekarang hamba tetanjak lagi pada Padoeka, di atas langit ada berapa banjak bintang.

\footnotetext{
150 idoepnja tidoer sama sama, BT 1929: djikaloe tidoer tjampoer satoe selimoet.

151 dibikinken lagi boekan, BT 1884: ija boleh di bikin roda jang baroe, BT 1929: bolehlah bikin roda lagi.

${ }^{152}$ seperti orang bikin roemah ... kendati tjendela berdjentrek djentrek tida lawan pintoe satoe dia poenja terang, BT1884: ibarat bikin Roemah misti pake Panglari, soengoe ada tiga Djendela 6 Lobangnja, tiada boleh sama sebagi satoe Pintoe poenja trang, BT 1929: seperti seboeah roema, tentoe dapet pintoenja jang besar, 3 djendela besar 6 djendela ketjil, tiada seperti satoe pintoe sadja empoenja terang. In Javanese, cagak is "pole, post," ngerentep is "lined up in rows," blandar is "roof frame," and djentrek is "row."

${ }^{153}$ menjegoel, BT 1884: $\varnothing$. Meaning unknown.

${ }^{154}$ Hian Tjaij Hian Tjaij (shan zai, shan zai): shan is "excellent," while zai expresses admiration. My thanks to Claudine Salmon for this explanation.

155 tjangak, BT 1884: bio, Javanese version: cangak.

${ }^{156}$ Ketigo and rendheng are Javanese, meaning the dry and wet season, respectively; the meaning here is

"whatever the season, all year long."

${ }^{157}$ koeda, BT 1884: kodok, BT 1929: kodok dan bangkong, Javanese version: kodok kongkang.
} 
Khong Hoe Tjoe saoetin.

Ja kami tanjak pada kau di atas boemi kenapa kau tanjak di atas langit poenja, perkara.

Hang Thok bilang kaloe Padoeka soeroe hamba tanjak di atas boemi baik di atas boemi ada brapa roemah.

Khong Hoe Tjoe mendjawab.

Ja kita bitjara jang ada di depan moeka mata kenapa kau bitjara di atas langit dan di boemi.

Hang Thok berkata lagi.

Baik kaloe Padoeka maoe tjerita di depan mata, Padoeka poenja boeloe alis ada brapa banjaknja.

Di sitoe wali Khong Hoetjoe trada bisa mendjawab lagi lantas berkata.

Kita tiada kira ini anak begini pinter barangkali titisnja dewa dateng di sini ${ }^{158}$.

Dan itoe wali abis berkata lantas naik kretanja prentah pada moeridnja soeroe poeter djalan poelang ke roemahnja dengen dia bitjata kendiri he! anak begitoe ketjil tiada kira begitoe pinternja.

Serta moerid moerid jang mengikoet bitjara begini, ho seng kowi hianti laitja tji poet dji kim ja (selamanja kita poenja wali pigi di lain lain negri beloen tahoe seperti ini waktoe.) $)^{159}$

Khong Hoe Tjoe lantas teroes poelang tiada kedjadian mengadjari soerat soerat orang di itoe negri. ${ }^{160}$

\section{Tamat}

Dari T. T. La

[English Translation]

Story of the Chinese Saint Khong Hoe Tjoe Who Was Teaching Chinese Literature to the Chinese Peoples

In ancient times there was a Chinese saint ${ }^{161}$ named Khong Hoe Tjoe. One day, he decided to go and teach the people of the Islamic country at the rear of the town of

\footnotetext{
158 begini pinter barangkali titisnja dewa dateng di sini, BT 1884: begini pinter ija dari mana datengnja.

159 The beginning (ho seng kowi [hou sheng ke wei yan], meaning "youngsters are to be feared") is not tranlated in the text, while the rest of the sentence (hianti laitja tji poet dji kim ja) is not clear and does not correpond to the translation. My thanks to Claudine Salmon for this explanation.

160 tiada kedjadian mengadjari soerat soerat orang di itoe negri, BT 1884: tiada djadi pegi mengadjar soeratsoerat di Negri bangsa Slam adanja.

${ }^{161}$ Confucius is usually called a "prophet" (Nabi Khong Hu Cu). Here, the word wali seems to refer to another category of spirituality. In the above-mentioned Sair Tiong Hwa Hwe Kwan Batavia, stanza 67, both words are used: "Nabi Kong Hoe Tjoe sebagi wali."
} 
Lokok. ${ }^{162}$ He thus stepped into a cart, accompanied by his disciples (the students of his school). Half way, he saw four little boys playing and joking together, while another one was busy piling up stones, shaping them in the form of a fortification and thus blocking the road. At this sight, the saint Khong Hoe Tjoe stopped his cart and asked the boy who was not playing:

- He! Why don't you play with your friends?

- Their games are useless. They may tear their shirts and dirty their pants. I am afraid of my mother and my father at home. If my shirt and pants are torn, they will surely be angry at me, moreover they will be at pain, having to buy me new clothes. Not to say that I myself will get tired. Those games are a waste; that's why I don't want to join.

The saint Khong Hoe Tjoe then said:

- In that case, why do you make this toy-fort in the middle of the road? Take it away immediately, I want to go through with my cart.

The boy retorted: the forts.

- O my lord, as much as I know, forever it has been the carts that gave way, not

Hearing such a remark, the saint Khong Hoe Tjoe stepped down from his cart and said:

— He! You are just a boy, how dare you twist the facts?

Replied the boy:

- O my lord, at the age of three, a child can part with his mother and father; three months after being born, a mouse deer can run about the forest; three days after being born, a fish can swim around in a deep river. This has been ordered by God the Almighty. So, it cannot be said that I am twisting the facts.

The saint said:

- Let me ask you, in what village and what district do you stay? What is the name of your family and what is your own? What is the name of your school?

The boy answered in a humble way:

- I stay in a forlorn place in the mountains. My family name is Hang and my own name Thok. I have no school yet.

The saint said:

- I wish to invite you to an excursion, what do you think?

Answered Hang Thok:

- O my lord, don't get upset, but I must take care of my mother and father at home; I love them very much and I have to look after them. There is also my older

${ }^{162}$ Lokok (Rukok in the Siamese version) is a rendering, probably through the Cantonese, of Lu kuo, "the country of Lu," that is the native state of Confucius, in the Shandong province; see Soymié, "L'entrevue de Confucius et de Hiang T'o," 361. 
brother, whom I must obey, and my younger brother, whom I must teach, and a master I must learn from. How could I go on an excursion with you?

The saint spoke:

- I have 32 cards of the Chinese tiger game ${ }^{163}$ in my cart and I would like to invite you to a game; what do you think?

Hang Thok replied:

- When the king plays games the country is left unattended; when the minister of war plays games nobody looks after his troops; if I played instead of learning my lessons I would certainly forget the master's teachings; when a merchant plays games he loses all his properties; when a slave plays games his master will surely give him the rattan; when a farmer plays games the sowing is delayed. This is why I have no wish to play.

Spoke the saint:

- Well, I want to invite you to make the country even; what do you think ${ }^{164}$

Hang Tok replied:

- One may not make the country even. There are high mountains, there is the sea large and deep, there are people of rank and laborers. If the mountains were flattened, the birds and animals in the forest would have no place left. If the sea and the rivers were filled in, where would the fishes and all that live in the sea stay? If there were no man of rank, people of low standing would not know the right from the wrong. If there were no laborers, there would be no way to know the masters. The world may not be made even.

The saint replied by a question:

- In the realm of the world, do you know what fire has no smoke, what water has no fish, what mountain has no stone, what tree has no branch, which man has no wife, which woman has no husband, which buffalo has no pen, which horse has no rider, which man can be a palace official and which a laborer, what can be less, what can be more, what town has no market, what person has no school?

Hang Thok answered:

- O my lord, for what I know, fireflies emit no smoke; a well has no fish; an earthen mount has no stones; an old denuded tree has no branch left; gods have no wives; fairies have no husbands; a wooden horse ${ }^{165}$ has no rider; an earthen buffalo ${ }^{166}$ has no pen; a smart person can be a palace official; an ignorant one will be a laborer; the tenth Chinese month has more days, there is an excess; the sixth Chinese month has fewer days, there is a shortage; the king's town has no market; the child has no school.

\footnotetext{
${ }^{163}$ The game in question is probably the Chinese card game called cuki; ibid., 353.

${ }^{164}$ The phrase is puzzling. Dede Oetomo suggests a pun in the Javanese version (on rat, "the world," and ngerat a, "to flatten"). The modern Chinese version has "to level off" without comment.

165 This wooden horse might be a horse made of bamboo (a kind of jaranan or kuda keping) that was already used as a toy by boys since the Han dynasty, or a horse made of wood for gymnastic pracice, if such a thing was already known under the Tang (Soymié, "L'entrevue de Confucius et de Hiang T'o").

${ }^{166}$ In ancient China people used to make oxes out of clay for the opening ceremony of spring (ibid., 321).
} 
To be continued.

[The second installment begins here.]

The saint asked again:

- He! Do you know the course of heaven and earth? And about this world and the hereafter, [how long is it] from head to tail, which is right and which is left, which is outside and which inside, which is the father and which the mother, which is male and which female? Where does the wind come from, where does rain have its origin, where does the smoke spring from, where do the clouds come from, how many miles long are heaven and earth?

Hang Thok answered:

- O my lord, the course of the earth is nine by nine, that is eighty-one surely. From head to tail, this world and the hereafter have eight by nine, that is, seventy-two. Heaven is the father, earth the mother. The sun is male, the moon female. East is called right, West is called left. A nephew is an external kin, a grandfather an internal one. The wind is seen by the leaves. Rain is the tears of the mountains. Smoke comes out of mountains, mist springs from the earth. Heaven and earth are hundreds of millions apart. ${ }^{167}$ East, West, North, and South are their [frontiers]. ${ }^{168}$ If you don't trust me, please measure them yourself.

The saint spoke again:

- He! According to you, who is closer: one's father and mother or one's wife?

Answered Hang Thok:

- O my lord, I believe father and mother are closer.

Then for the first time the saint could retort:

- He! How can you say that father and mother are closer than husband and wife, because all their life long, husband and wife share the same bed, and when they die they are both put in the same grave. How could mother and father be closer as you say?

Hang Thok replied:

- O my lord, don't get upset. When a man's wife dies, it is like a carriage that has lost a wheel, one makes a new one, right? It can even be stronger, better, and more enjoyable. This is how it goes with husband and wife. When a house is built, it may have rows and rows of posts, they will not beat a roof frame; it may have lines of windows, they cannot give light as does a single door. Many stars scintillate in the sky, but their light can't compare with that of the one moon. The same goes with a father's and a mother's love: it is infinite.

Hearing these words, the saint Khong Hoe Tjoe took a long breath while saying:

\footnotetext{
${ }^{167}$ A keti is a hundred thousand.

${ }^{168}$ The text has "their ears," which makes no sense, while other Malay versions and the Chinese one have "frontiers."
} 
- Hian Tjaij Hian Tjaij (really clever, really clever), he is still a little boy but he is more clever that all old men together.

Seeing the saint taking a breath, Hang Thok asked in his turn:

- Well, all the questions you asked me I have answered one by one. Now I will ask you some. Please don't get angry or upset. How are geese and ducks able to swim? ${ }^{169}$ Why do herons have a shrieking voice? Why are the banyan tree's leaves permanently green?

Khong Hoe Tjoe answered:

- Geese and ducks can swim because they have large and short feet. Herons have a shrieking voice because they have a long neck. Banyans have green leaves because they have a hard core.

Hang Thok replied:

- $\mathrm{O}$, certainly not! Fish can swim, do they have large and short feet? Horses have a loud voice, do they have a long neck ( $^{170}$ Bamboo has permanent green leaves, does it have a hard core? And now let me ask you: how many stars are there in the sky?

Khong Hoe Tjoe answered:

- Well, I asked you about the earth, why should you ask about heavenly matters?

Hang Thok then said: earth?

- If you require me to ask about the earth, well, how many houses are there on

Khong Hoe Tjoe answered:

- We are talking about what is in front of our eyes, why do you ask about heaven and earth?

Hang Thok said:

- Good, if you wish to talk about what is before our eyes, how many hairs are there in your eyebrows?

Then the saint Khong Hoe Tjoe could not answer; he just said:

- We would never have guessed that this boy was so clever; maybe he is a reincarnation of a god.

Having said so, the saint climbed into his cart and ordered his disciples to turn back and go back home, while saying to himself: He! Such a young boy, who would guess he is so clever?

\footnotetext{
${ }^{169}$ The text has "raise above the water," but, apparently, with the meaning of "staying above the water," that is, "swimming," which fits better with "fish," below. Both Chinese ancient and modern versions have "to swim."

170 "Horses" is an unfortunate example, because they are not famous for their loud voice and they do have a long neck; the ancient Chinese version has the much better example of frogs.
} 
The disciples who were with him exclaimed (in Chinese): ho seng kowi hianti laitja tji poet dji kim ja (all the time our saint has visited other countries, this has never happened before).

Khong Hoe Tjoe then went home directly without teaching Chinese letters in that country.

The end.

From T. T. La 